\title{
Archaeal Genetics - The Third Way
}

Thorsten Allers ${ }^{1}$ and Moshe Mevarech ${ }^{2}$

Institute of Genetics, University of Nottingham, Queen's Medical Centre, Nottingham NG7 2UH, UK ${ }^{1}$

Department of Molecular Microbiology and Biotechnology, George S. Wise Faculty of Life Sciences, Tel Aviv University, Tel Aviv 69978, Israel $^{2}$

Correspondence to T.A.

e-mail: thorsten.allers@nottingham.ac.uk

DOI: $10.1038 / n r g$

Abstract | For decades, archaea were misclassified as bacteria on account of their prokaryotic morphology. Molecular phylogeny eventually revealed that archaea, like bacteria and eukaryotes, are a fundamentally distinct domain of life. Genome analyses have confirmed that archaea share many features with eukaryotes, particularly in information processing, and therefore can serve as streamlined models for understanding eukaryotic biology. Biochemists and structural biologists have embraced the study of archaea but geneticists have been more wary, despite the fact that genetic techniques for archaea are quite sophisticated. It is high time for geneticists to start asking fundamental questions about our distant relatives. 
Ever since microbiology was established by Louis Pasteur and Robert Koch, scientists have wrestled with the problem of defining the phylogenetic relationships among bacteria. Classical taxonomy, which relies on cell morphology, physiology, and pathogenicity, is useful for identifying specific microorganisms. However, it fails to establish meaningful evolutionary relationships that can be used to group species into higher taxonomical orders. Carl Woese's solution was to harness the newly-emerging techniques of nucleic acid sequencing, and use small-subunit (SSU) ribosomal RNA nucleotide sequence as a universal molecular chronometer (Box 1). When he published his findings in 1977, Woese upset the taxonomic applecart by suggesting that prokaryotes are a great deal more diverse than we had previously supposed, and that the phylogenetic structure of the prokaryotic DOMAIN should be reassessed ${ }^{1}$.

What he found was that a group of anaerobic "bacteria", which had been studied for years due to their unique ability to generate methane, are not bacteria at all. There had been inklings that these microbes have rather "unbacterial" aspects, such as the presence of N-linked glycoproteins and a peculiar spectrum of antibiotic sensitivity. The rRNA phylogeny revealed that they are no more related to typical bacteria than they are to eukaryotes, and Woese therefore renamed this group of microorganisms archaebacteria ${ }^{1}$. In a subsequent paper, he shortened the name to Archaea and suggested that this domain be given equal footing with Bacteria and Eukarya ${ }^{2}$. Unsurprisingly, this proposal ran into stiff resistance.

Despite numerous attempts to square the taxonomic circle, the three-domain organisation has stood the test of time (Box 1). We now recognise that the domain Archaea is home to a great number of microbes that were previously misclassified as bacteria on account of their prokaryotic morphology. Archaea are clearly MONOPHYLETIC, and their status is underpinned by unique features such as a distinctive cell membrane utilising isoprene side-chains that are ether-linked to glycerol ${ }^{3}$. The SSU rRNA tree also reveals several archaeal phyla, which exhibit biological differences that underpin their taxonomic split. For example, euryarchaeota contain histones that are strikingly similar to eukaryotic homologues, whereas crenarchaeota use completely different DNA-binding proteins ${ }^{4}$. Further insights has come from genome sequencing projects, which have shown that archaea are a chimera of bacterial and eukaryotic features; their core metabolic functions resemble those of bacteria, whereas information processing functions have a distinctly eukaryotic flavour. One feature that appears to unite archaea is their ability to thrive in harsh and unusual environments (Box 2); it is because these organisms are so well suited to conditions that might have existed on the early (archaean) earth that Woese gave them their name. However, it would be misleading to think that all archaea are EXTREMOPHILES. Recent environmental studies have shown that archaea are much more widespread than previously thought, and might constitute as much as $20 \%$ of the total biomass ${ }^{5}$.

As the domain Archaea has become widely accepted, so researchers have turned to these fascinating microorganisms for answers to some of biology's most pressing questions. Owing to molecular features they share with their more complex cousins, archaea have served well as a streamlined model for eukaryotes, particularly in the field of DNA replication ${ }^{6}$ (discussed in detail later). On the other hand, the ability of 
archaea to thrive at high temperature and salinity has endeared them to structural biologists, who have found thermostable and halophilic proteins to be a great boon. For example, the first crystal structure for a ribosome was obtained using the large ribosomal subunit from Haloarcula marismortui ${ }^{7}$. Archaeal enzymes are now routinely exploited as a source of high-quality structural data that can be used to predict functional interactions in eukaryotic systems, particularly in fields related to information processing such as DNA repair ${ }^{8}$. Exploitation of the extremophilic features of archaea for biotechnology has yet to bear fruit ${ }^{9}$. Of the few examples in current use, those familiar to most scientists are the thermostable enzymes used for DNA amplification by PCR (e.g. Pfu DNA polymerase from Pyrococcus furiosus). However, the potential of archaea for biotechnological applications is significant. For example, the ability of METHANOGENIC archaea to thrive under anaerobic conditions means they are ideally suited for bioremediation in anoxic sludge, such as marine coastal sediment. Furthermore, the methane they generate by anaerobic digestion of manure can be used as a fuel source. Finally, we should not underestimate the ecological impact of archaea; since methane is a powerful greenhouse gas, these organisms might be partly responsible for global warming.

With all the interesting aspects of archaea, why do so few scientists work on this domain of life? A significant factor is the perceived lack of genetic systems. Archaea, or at least the ones that are cultivable, are renowned as extremophiles, and organisms that thrive in boiling acid are not conducive to routine genetic techniques. Furthermore, when faced with sophisticated model organisms such as Escherichia coli or Saccharomyces cerevisiae, it is understandable that scientists are reluctant to switch domain. Unfortunately, this means that numerous biochemical and structural studies on archaea are not being underpinned by in vivo data; Escherichia coli and Saccharomyces cerevisiae have been such successful models precisely because of the synergy of biochemistry and genetics. In this review, we aim to show that archaeal genetics is a great deal more advanced than is commonly believed. We will survey the current state of genetic systems - the difficulties in establishing genetic tools for archaea will be set out, followed by an update of methodologies in current use. We will also review the field of archaeal genomics, illustrating how data from genome projects have lead to a reappraisal of the phylogenetic status of archaea, and how the striking similarity between archaeal and eukaryotic information processing systems has stimulated a new generation of researchers to seek answers in the third domain. 


\section{Archaeal genomics - lessons from genome comparisons}

While the DNA sequencing revolution of the late 1970s gave birth to the domain Archaea, it was the genome sequencing revolution of the last decade that enabled the archaeal concept to pass from adolescence to maturity. In retrospect, it was fortuitous that one of the first genome sequences to be published was of the methanogenic archaeon Methanococcus jannaschii (now renamed Methanocaldococcus jannaschii; see Table 1$)^{10}$. The new discipline of genomics stimulated interest in these exotic microorganisms, as biologists found their genes of interest in a novel context. Archaea proved to be a mosaic of molecular features, which are encoded by two different groups of genes: a lineage coding for information processing that is eukaryotic in nature, and a lineage coding for operational (housekeeping) functions with a bacterial aspect ${ }^{11}$. This tidy schism is not inviolable, for LATERAL GENE TRANSFER can lead to conflicting phylogenetic signals when any one archaeal species is examined in isolation ${ }^{12}$ (see Box 1). According to the complexity hypothesis of Jain \& Rivera, informational genes are less prone to lateral transfer than operational genes, as the former are typically members of large complex systems ${ }^{13}$. However, the comparison of complete genome sequences has revealed that archaea are far more than a sum of their (eukaryotic and bacterial) parts ${ }^{14}$. More than anything else, it is the high fraction (as much as $50 \%$ ) of archaeal genes with no clear function that should prompt experimental biologists to reclaim the initiative in a post-genomic era.

Transcription and translation. The revelation that archaeal and eukaryotic information processing systems are similar predates genome sequencing, and was noted in the 1980s by Wolfram Zillig and colleagues in studies of DNA-dependent RNA polymerases ${ }^{15}$. The core components of the archaeal and eukaryal (RNA polymerase II) enzyme more closely related to each other than to the bacterial version, and the archaeal holoenzyme contains additional subunits that have counterparts in eukaryotes but not bacteria. Like eukaryal RNA polymerase II, the archaeal enzyme requires additional basal factors for efficient promoter recognition, including TATA-box binding protein (TBP) and transcription factor B (TFB) ${ }^{16}$. Many archaea contain multiple homologues of TFB and/or TBP that might play distinct roles in transcription; for example, expression of one TFB is upregulated in response to heat shock of Haloferax volcanii ${ }^{17}$. Nevertheless, the basal transcription machinery in archaea is much simpler than the eukaryotic system, and therefore is more amenable to analysis. This should lead to a better understanding of the many small subunits conserved between archaeal and eukaryal RNA polymerases.

To considerable surprise, genome analysis has revealed that archaea also encode numerous homologues of bacterial transcription regulators ${ }^{18}$. This suggests that archaea might use a bacterial mode of transcriptional regulation where repressors binds at operator sites near the promoter and interfere directly with initiation. Indeed, such repressors have been studied in vivo in Archaeoglobus fulgidus and Methanococcus maripaludis $^{19,20}$. However, other systems are more reminiscent of eukaryotic regulation. In an elegant genetic analysis of gas vesicle synthesis genes from Halobacterium salinarum, Felicitas Pfeifer and colleagues have shown that transcriptional activation by GvpE involves binding upstream of the TFB recognition element, 
most likely leading to direct contact with the basal machinery ${ }^{21}$. It is noteworthy that GvpE resembles a basic leucine-zipper (bZIP) protein, a motif that is commonly found in eukaryotic regulators.

Translation in archaea has been studied much less intensively than transcription, but the message is similar ${ }^{22}$. The core components (such as rRNA) are eukaryal in nature, as are the levels of complexity - more than 10 initiation factors are found in archaea and eukaryotes, whereas bacteria require only 3. Similarly, translation initiation in archaea and eukaryotes uses methionine, while bacteria use $\mathrm{N}$-formylmethionine. On the other hand, both bacteria and archaea use polycistronic mRNAs, and recognition of mRNA by the ribosome is often by means of a purine-rich Shine-Dalgarno sequence in the $5^{\prime}$ untranslated region. It should be noted that a second mechanism for translation initiation is used in archaea, which operates on leaderless mRNAs and is therefore more reminiscent of the eukaryotic pathway ${ }^{23}$. Studies of these two mechanisms, and the circumstances under which they are used, should shed light on the origins of translation initiation.

Chromatin. The octameric nucleosome, consisting of two copies each of the histones H2A, H2B, H3 and $\mathrm{H} 4$, has long been considered a hallmark of the eukaryotic cell. Since prokaryotes were thought not to require such a baroque machinery for DNA compaction, it came as a considerable surprise when the laboratory of John Reeve reported that the methanogenic archaeon Methanothermus fervidus contains a homologue of eukaryotic histones ${ }^{24}$. Genome sequencing has revealed that histones are widespread amongst euryarchaeota but absent from crenarchaeota ${ }^{4}$.

Archaeal histones dimerise to form a structure resembling the eukaryotic H3-H4 dimer, and assemble into a tetramer to bind $\sim 60$ base pair (bp) of DNA. However, archaeal histones lack the $\mathrm{N}$ - and C-terminal tails that are sites of regulatory posttranslational modification in eukaryotes, suggesting that chromatin remodelling is not used as a mode of gene regulation in archaea ${ }^{25}$. By contrast, nucleoid proteins found in crenarchaeota, such as Alba, undergo posttranslational modification; a significant proportion of Alba is acetylated at lysine residues, and deacetylation (which is mediated by Sir2) leads to transcriptional repression ${ }^{26}$. The lysine acetylase that acts on Alba was recently identified (S. Bell, personal communication), and should be a fruitful area of further study.

DNA recombination and repair. There is considerable interest in studying DNA recombination and repair systems in archaea, as they commonly have to contend with harsh conditions that threaten genomic stability $^{27}$. Furthermore, these are highly complex repair processes, doubly so in eukaryotic cells, which have a specialised programme of meiotic recombination. The potential of archaeal genomics was plainly demonstrated when homology to an archaeal topoisomerase led to the identification of Spo11 as the eukaryotic enzyme responsible for double-strand breaks that are formed during meiosis ${ }^{28}$.

Strand exchange is the cornerstone of DNA recombination, providing the means to identify and synapse with an homologous template, and is carried out by proteins of the RecA family. The archaeal homologue (RadA) shows greater similarity to the eukaryotic sequence $(\operatorname{Rad} 51)$ than the bacterial one $(\operatorname{Rec} A)$. The resemblance is even more striking at the structural level, to the point where functional interactions between eukaryotic 
proteins can be extrapolated from the archaeal crystal structure ${ }^{8}$. RadA has been shown to promote strand exchange in vitro ${ }^{29}$, and a radA mutant of $H f x$. volcanii has been generated that is defective in recombination and highly sensitive to DNA damage ${ }^{30}$. A RadA paralogue, RadB, has been identified in the genome sequences of euryarchaeota. RadB has no strand exchange activity ${ }^{31}$, and $\operatorname{radB}$ mutants of $H f x$. volcanii are not defective in recombination (T.A. unpublished observations). Genetic studies of RadB, which are underway in one of our laboratories (T.A.), should provide some insight into the function of eukaryotic Rad51 paralogues; these are largely of unknown function and have no counterparts in bacteria.

Other forms of DNA repair involve either excision or direct reversal of the lesion. The archaeal homologue of eukaryotic XPF (Rad1), a nuclease that recognises junctions between single and double-stranded regions of DNA, might function in excision repair. Intriguingly, crenarchaeal XPF lacks the N-terminal "helicase" domain present in the euryarchaeal and eukaryotic proteins ${ }^{32}$. An example of direct reversal of DNA damage is the photoreactivation system, which uses photolyase to act on pyrimidine dimers. While this enzyme is not widespread amongst archaea, it is found in HALOPHILES that are commonly exposed to solar radiation ${ }^{33}$. Most archaea also lack homologues of $m u t S$ and mutL genes, which encode the mismatch repair machinery that is conserved from E. coli to humans. In spite of this, genetic studies of Sulfolobus acidocaldarius have shown that archaea are just as efficient at repairing DNA damage as $E$. coli ${ }^{34}$, suggesting that novel pathways of DNA repair have yet to be discovered. Such a repair system for THERMOPHILIC archaea has been predicted by genome sequencing and analysis ${ }^{35}$, and awaits genetic studies.

DNA replication. Archaea and bacteria share a genomic structure, usually consisting of a single circular chromosome, but differ in the machinery used to carry out DNA replication ${ }^{6}$. As with other aspects of information processing, the archaeal proteins are more similar to eukaryotic homologues than bacterial ones. Since only a subset of the eukaryotic proteins are found in archaea, the latter system is considerably simpler and is therefore more amenable to dissection. The laboratory of Hannu Myllykallio used genome analysis to predict (and biochemistry to confirm) the location of the chromosomal replication origin in Pyrococcus abyssi $^{36}$. This prediction was based on the observation that leading strands of replication often contain an excess of $\mathrm{G}$ over $\mathrm{C}$ nucleotides. The origin of replication is highly conserved amongst the three Pyrococcus species examined (P. furiosus, P. abyssi and P. horikoshii), and the identity of gene cluster located in this region is of particular interest. In addition to sequences encoding RadB (discussed above), a single gene similar to eukaryotic $c d c 6$ and $\operatorname{orcl} 1$ is found directly adjacent to the origin; orcl codes for a subunit of the eukaryotic origin recognition complex, suggesting that Cdc6/Orc1 acts as the initiator protein in archaea. This is indeed the case ${ }^{37}$, and almost every archaeal chromosomal replication origin identified to date is adjacent to a cdc6/orcl gene ${ }^{6}$. The exception is intriguing: both $S$. acidocaldarius and $S$. solfataricus have three $c d c 6 / o r c 1$ genes and three replication origins, but only two of these colocalize ${ }^{38,39}$. Even more mystifying is why some species of haloarchaea (such as Halobacterium species NRC-1) should require 10 distinct $c d c 6 /$ orcl genes. This is a question that genetics is best placed to answer.

Central metabolism and energy conversion. It is commonly stated that operational genes in archaea (coding 
for central metabolism, energy conversion and biosynthesis) are bacterial in origin ${ }^{11}$. As with the comparison between archaeal and eukaryotic informational genes, this statement is more of a soundbite than a true representation of archaea. For instance, methanogenesis is not found in any bacteria. Genome analysis of Methanosarcina acetivorans has revealed a surprising diversity of methanogenic pathways that utilise acetate and a variety of one-carbon compounds (acetoclastic and methylotrophic pathways, respectively) ${ }^{40}$. However, M. acetivorans is unable to reduce $\mathrm{CO}_{2}$ using $\mathrm{H}_{2}$ (the hydrogenotrophic pathway), as this species lacks the ferredoxin-dependent hydrogenase encoded by the ech operon. The pivotal role of this enzyme has been confirmed by genetics studies in Methanosarcina barkeri, which have demonstrated that mutants lacking Ech are unable to grow on $\mathrm{H}_{2} / \mathrm{CO}_{2}$ alone ${ }^{41}$.

Amongst HETEROTROPHIC archaea, a significant fraction can metabolise sugars. While glycolytic pathways are well conserved in bacteria and eukaryotes, archaea use several variant enzymes that can best be explained by independent, convergent evolution ${ }^{42}$. Support for variant metabolic pathways in archaea has come from a number of studies, such as the prediction of a novel aconitase family by comparative genome analysis ${ }^{43}$. Aconitase is an essential part of the tricarboxylic acid cycle, and the canonical gene is found only in a minority of euryarchaea. Similarly, genome analysis has indicated that many archaea, such as the HYPERTHERMOPHILIC crenarchaeon Thermoproteus tenax, lack the enzymes for an oxidative pentose phosphate pathway (PPP) ${ }^{44}$. Since pentoses are essential for anabolic purposes, it is likely that archaea use a variant PPP encoded by genes with no obvious bacterial or eukaryotic homologues. Thus, while it is true that well-conserved operational genes in archaea are most similar to their counterparts in bacteria, there are many novel or variant enzymes that await discovery. Genomics can point the way, but genetics and biochemistry must work hand in hand to unravel these mysteries. 


\section{Archaeal genetics - back to basics}

In the early years of archaeal genetics, the development of markers and transformation protocols were intimately linked - without a selectable phenotype it is impossible to score transformation efficiency, and vice versa. This impasse was due to the scarcity of archaeal antibiotics. Bacterial antibiotics such as ampicillin are safe for medical use because their targets, such as peptidoglycan cell walls, are not encountered in eukaryotic cells. Since these drug targets are also absent from archaea, it is not surprising that such antibiotics are ineffective in the third domain. The issue of selectable markers is discussed in a later section. Here, we summarise the methods available for introducing foreign DNA in archaeal cells.

Transformation. To circumvent the bottleneck of developing transformation protocols without genetic markers, researchers turned to unconventional methods. Cline and Doolittle assayed TRANSFECTION of Halobacterium halobium with naked DNA from phage $\Phi H^{45}$, enabling them to develop an efficient polyethylene glycol-mediated transformation method for $H f x$. volcanii ${ }^{46}$, which was subsequently adapted for use in a variety of archaea including M. maripaludis and Pyrococcus abyssi ${ }^{47,48}$. It is only effective in species for which SPHEROPLASTS can be generated readily, usually by removing the paracrystalline glycoprotein surface layer (S-layer). By contrast, archaea with a rigid cell wall made of pseudopeptidoglycan, such as Methanothermobacter thermautotrophicus, have been recalcitrant to transformation. Although it is possible to remove the cell wall enzymatically using pseudopeptidoglycan endopeptidase, the protoplasts fail to regenerate (J. Chong, personal communication).

Other transformation protocols have been used with varying success (see table in Box 3). Electroporation is a versatile technique and can be used for Methanococcus voltae and $S$. solfataricus ${ }^{49-51}$, but is inefficient in species such as $M$. acetivorans ${ }^{52}$. Furthermore, it is not universally applicable; $P$. abyssi cannot be transformed by this method ${ }^{48}$, and electroporation is out of the question for halophilic archaea, which cannot tolerate salt concentrations of $<1 \mathrm{M} \mathrm{NaCl}$. Heat-shock after treatment with $\mathrm{CaCl}_{2}$, a method commonly used for E. coli, can be used with some archaea but is not efficient. It is noteworthy that in Thermococcus kodakaraensis, $\mathrm{CaCl}_{2}$ treatment is not essential for DNA uptake ${ }^{53}$; this is reminiscent of natural transformation, which has been observed in M. voltae ${ }^{54}$. Efficient transformation of Methanosarcina species is only possible using a liposome-mediated protocol, which yields $>10^{7}$ transformants per microgram of DNA. The drawback of this method is that the requisite cationic liposomes are expensive.

Other gene transfer mechanisms. Once the DNA is safely inside an archaeal cell, it can be transferred to its neighbours by various means. Phage-mediated TRANSDUCTION is a mainstay of $E$. coli genetics, and similar phenomena have been reported in Methanobacterium thermoautotrophicum Marburg ${ }^{55}$ and M. voltae ${ }^{56}$. In the latter case, the jury is still out; there is no evidence that gene transfer in M. voltae is mediated by viral particles $^{56}$, and the observation that the transfer agent is resistant to DNase does not rule out alternative routes. For example, bidirectional genetic exchange has been observed during cell mating in $H f x$. volcanii ${ }^{57}$, which involves cell-to-cell contact or fusion rather than transduction, and is actually stimulated by DNase 
treatment $^{58}$. Similar cell mating has also been seen in $S$. acidocaldarius and $S$. solfataricus. In the former, chromosomal marker exchange between two AUXOTROPHIC mutants can be measured by the appearance of stable genetic recombinants ${ }^{59}$. In the latter, conjugative plasmids such as pNOB8 have been shown to propagate throughout the culture using a cell-to-cell contact-dependent mechanism ${ }^{60}$. The kinetics of cell mating in Sulfolobus differs from that in Hfx. volcanii, as it does not require that cell-to-cell contacts are stabilised by growth on solid media ${ }^{58,61}$.

Restriction/modification systems. From the perspective of foreign DNA, the inside of a cell can be a hostile environment. Restriction/modification systems are widespread amongst prokaryotes, and archaea are no exception. Enzymes that recognise 5'-CTAG-3' are common, having been identified initially in Methanobacterium thermoformicicum, where they are plasmid-encoded ${ }^{62}$. Genome analysis has revealed putative CTAG methylases in many species (restriction endonucleases are virtually impossible to identify by sequence homology), and DNA isolated from $H f x$. volcanii is resistant to cleavage at NCTAGN' sites, suggesting modification ${ }^{46}$. Hfx. volcanii also has a restriction system that recognises adenine-methylated GATC sites (which occur frequently in vectors based on E. coli plasmids), resulting in DNA fragmentation followed by plasmid loss or chromosomal integration by recombination ${ }^{63}$. This can be circumvented by passaging the DNA through an E. coli dam $^{-}$strain that is deficient in GATC methylation ${ }^{64}$. Other restriction/modification systems have been documented, such as the SuaI enzyme of S. acidocaldarius that recognises $5^{\prime}-\mathrm{GGCC}-3^{165}$.

Antibiotics. While most bacterial antibiotics are ineffective in archaea, several exceptions have been exploited to develop selectable markers for archaeal genetics (see Table 2). Novobiocin is a potent inhibitor of DNA gyrase $(\operatorname{gr} B)$, an enzyme present in both bacteria and archaea. To develop a vector for halophilic archaea, the laboratory of Mike Dyall-Smith isolated a novobiocin-resistant mutant of Haloferax strain Aa2. $2^{66}$ that mapped to the $g y r B$ gene ${ }^{67}$. Puromycin is another drug that is effective in both bacteria and archaea, and has been shown to inhibit growth in $M$. voltae and other methanogens ${ }^{68}$; it is the most widely used antibiotic for this group of archaea. The resistance marker (puromycin transacetylase) is a bacterial gene from Streptomyces alboniger. Owing to differences between bacterial and archaeal gene regulation, it is transcribed using an $M$. voltae promoter ${ }^{69}$. A similar approach was used to generate a construct for neomycin resistance in M. maripaludis (using APH3'I and APH3'II genes from Tn903 and Tn5 respectively ${ }^{70}$ ).

By contrast, the gene for pseudomonic acid resistance originates in archaea, and was generated by mutagenesis of the isoleucyl-tRNA synthetase gene from Methanosarcina barkeri ${ }^{71}$. Similarly, resistance to mevinolin, a 3-hydroxy-3-methylglutaryl coenzyme A (HMG-CoA) reductase inhibitor, was isolated from a spontaneous $h m g A$ mutant of $H f x$. volcanii ${ }^{72}$. However, pseudomonic acid is not available commercially, and mevinolin is difficult to obtain as it is licensed as a cholesterol-lowering drug; by inhibiting the conversion of acetyl-CoA to mevalonic acid, mevinolin prevents the synthesis of cholesterol in humans and isoprenoid lipid side-chains in archaea. There are additional drawbacks to these antibiotics: spontaneous resistance can arise at high frequency due to gene amplification, and plasmids bearing mevinolin or novobiocin markers 
suffer from instability due to homologous recombination with the chromosome (both these markers were derived from Haloferax species and are virtually identical to the chromosomal sequence of $H f x$. volcanii). This instability can be alleviated by using markers from distantly related species, such as the mevinolinresistant $h m g A$ mutant allele from Haloarcula hispanica ${ }^{73}$.

Auxotrophic selectable markers. Plasmid instability due to recombination could also be prevented by deleting the homologous chromosomal gene. Although this is not possible for mevinolin and novobiocinresistance markers (both $h m g A$ and $g y r B$ are essential), it is feasible for genes in amino acid biosynthesis and other metabolic pathways where auxotrophic strains can easily be complemented. For example, a leuB deletion mutant defective in leucine synthesis can be grown on complete media, unless selection for a plasmid-encoded leuB marker is required, in which case leucine-deficient media is used. Such an approach has been adopted in yeast genetics, as few bacterial antibiotics are effective against eukaryotic cells. In addition to leucine, strains auxotrophic for histidine, proline, tryptophan and thymidine have been isolated in several species (see Table 2 for details). The principal drawback with auxotrophic markers is that they cannot be developed easily in obligatory AUTOTROPHS, which includes most methanogens. However, many Methanosarcina and Methanococcus species are facultative autotrophs that readily take up amino acids, and are therefore compatible with auxotrophic markers ${ }^{74}$. To enable full exploitation of auxotrophic markers, it is best if the organism can be grown on chemically defined (minimal) medium, as is the case for P. abyssi ${ }^{75}$, $H f$. volcanii ${ }^{58}$ and M. maripaludis ${ }^{76}$.

Gene knock-out systems. Auxotrophic markers for uracil biosynthesis (ura3, pyrE or pyrF genes) are the most useful, as they can be COUNTER-SELECTED using 5-fluoroorotic acid (5-FOA); ura $^{-}$cells are resistant to this compound due to their inability to convert 5-FOA to the toxic analogue 5-fluorouracil. Such markers can be implemented in organisms that grow poorly on minimal medium, as complex media deficient in uracil (such as casamino acids) can be used. This has enabled the establishment of gene knock-out systems in Halobacterium $^{77,78}, H f x$. volcanii ${ }^{79,80}$, and T. kodakaraensis ${ }^{53}$ (see Table 2). The salient features of these systems are that the uracil marker can be reused (see Figure 1b), and that transformation is carried out using circular DNA (transformation using linear DNA is inefficient in some species). Uracil-auxotrophic mutants have also been isolated in P. abyssi ${ }^{48,81}$, S. acidocaldarius ${ }^{82}$ and $S$. solfataricus ${ }^{83}$, but gene knock-out systems have yet to be developed. A trivial problem is that Gelrite, the gelling agent used in solid media for hyperthermophiles, contains trace uracil $^{84}$ (see Box 3). More seriously, in the widely used S. solfataricus P1 and $\mathrm{P} 2$ strains, gene-targeting constructs fail to recombine with the chromosome ${ }^{83}$. While it is possible that recombination is suppressed in $S$. solfataricus due to active transposable elements ${ }^{84}$, Halobacterium also suffers from active transposition but is proficient for recombination ${ }^{85}$. Moreover, a different isolate of $S$. solfataricus is capable of homologous recombination, and has been used for gene knock-out experiments (using selection for lactose utilisation) ${ }^{86}$.

Counter-selectable markers have recently been developed for methanogens, using the purine salvage enzyme hypoxanthine phosphoribosyltransferase encoded by the hpt gene; mutants are resistant to the toxic base 
analogues 8-aza-2,6-diaminopurine and 8-azahypoxanthine ${ }^{87}$. Unlike uracil/5-FOA systems, gene knock-out with $h p t$ requires an additional marker, for positive selection of plasmid integration. Puromycin and neomycin-resistance markers have been used with $h p t$, to construct a $\Delta$ proC mutant of M. acetivorans ${ }^{88}$ and alanine-utilisation mutants of M. maripaludis respectively ${ }^{89}$.

Random mutagenesis. As mentioned earlier, homology to bacterial or eukaryotic enzymes can be used to predict the function of only half the proteins encoded by archaeal genomes. If we are to elucidate the function of the remaining half, we must move beyond targeted gene knock-outs. Random mutagenesis provides the means to uncover genes and reaction pathways that are unique to archaea. UV radiation and chemical mutagenesis (using ethyl methanesulphonate) have been used to isolate auxotrophic mutants of $H f x$. volcanii ${ }^{58}, M$. volta $e^{54}$ M. maripaludis ${ }^{90}$, and $P$. abyssi ${ }^{91}$. Since these mutations are difficult to map, transposon insertion mutagenesis has been attempted. In vitro transposition was used to study the nifH gene of $M$. maripaludis ${ }^{92}$, although mutagenesis was not random as a defined target (rather than the whole genome) was used. The laboratory of Bill Metcalf has developed an elegant in vivo transposition system for M. acetivorans using a modified version of mariner-family transposon Himarl, which carries a puromycinresistance marker as well as features that allow facile cloning of transposon insertions ${ }^{93}$. Unfortunately, this system is restricted to methanogens, as eukaryotic or bacterial transposons cannot function in the hypersaline interior of halophiles, or at the high temperatures demanded by hyperthermophiles. Synthetic transposons based on insertion sequences from $H$. salinarum have been constructed for use in $H f x$. volcanii, but have had little success ${ }^{94}$.

Random insertional mutagenesis is possible without transposition, so long as the species is proficient for homologous recombination. In this approach, recombination between a truncated version of the gene and its chromosomal copy leads to an insertion/disruption mutation (Figure 2B). A targeted version of insertional mutagenesis has been used in $M$. voltae, to characterise genes encoding flagellins and hydrogenases ${ }^{95-97}$. For random mutagenesis, a genomic library of small fragments (less than a full-length gene) is used to target recombination. As with the in vivo transposition system for $M$. acetivorans, insertion/disruptions are easily cloned by cutting and self-ligating genomic DNA fragments from the mutant, followed by introduction into E. coli (Figure 2B). Such random insertional mutagenesis has been used to isolate acetate auxotrophs of $M$. maripaludis ${ }^{98}$.

Plasmid vectors. There are two basic flavours of vectors for archaeal genetics: INTEGRATING PLASMIDS and SHUTTLE PLASMIDS (see Figure 2A and online resources). As their name implies, integrating (or suicide) plasmids must integrate into the host chromosome, as they do not have an origin of replication for archaea. They are usually employed in gene knock-out or insertion/disruption mutagenesis, where efficient homologous recombination is paramount. In strains where this is not possible, such as $S$. solfataricus $\mathrm{P} 1$ and P2 isolates, vectors based on the SSV1 virus have been used that integrate into the chromosome by sitespecific recombination ${ }^{83}$. SSV1 is also capable of stable replication as a circular plasmid, and this faculty has permitted the construction of recombinant shuttle vectors for S. solfataricus ${ }^{51,99}$. An intriguing feature of 
SSV1 (and derived vectors) is that it spreads efficiently in cultures without lysis of the host cells ${ }^{50}$. This conjugative behaviour eliminates the need for efficient transformation. Self-spreading is also seen with pNOB8, another plasmid of Sulfolobus ${ }^{60}$, but vectors derived from pNOB8 impose a significant burden on the host cell and have not been widely used ${ }^{100}$.

Shuttle vectors for other species are more conventional, and use replication origins cannibalised from plasmids indigenous to the host. For example, the shuttle vector in Figure 2A (pTA230) uses the origin from pHV2, a naturally occurring $6.4 \mathrm{~kb} H f x$. volcanii plasmid. As it is non-essential, $H f x$. volcanii could be cured of pHV2 by using ethidium bromide, thus generating the widely used strain WFD $11^{46}$; a strain cured of pHV2 without using ethidium bromide (DS70) has since been isolated ${ }^{73}$. The WFD11 strain enabled the laboratory of Ford Doolittle to develop shuttle vectors for halophilic archaea, using the pHV2 origin and a mevinolin-resistance marker ${ }^{72}$. To date, it remains the most commonly used replicon for use in $H f x$. volcanii. While pHV2-based plasmids are capable of replication in Halobacterium, a number of additional shuttle vectors have been derived from plasmids $\mathrm{pGRB} 1^{101}$ and $\mathrm{pHH} 1^{63}$. Interestingly, plasmids based on pHV2 and pHH1 fail to replicate in recombination-deficient radA mutants of $H f x$. volcanii ${ }^{30}$, but pHK2 replicons ${ }^{66}$ do not have this problem.

Shuttle vectors for methanogens are less common. The most useful replicon is based on the naturally occurring plasmid pC2A from M. acetivorans. The laboratory of Bill Metcalf has developed a series of pC2A derivatives, using puromycin-resistance as a selectable marker, and demonstrated that they are capable of transforming a variety of Methanosarcina species $^{52}$. Shuttle vectors for use in M. maripaludis have been derived from the cryptic plasmid pURB500. Early incarnations suffered from instability in E. coli hosts, most probably due to the high $\mathrm{A}+\mathrm{T}$ content of the replicon $(\sim 70 \%)^{102}$; stable vectors featuring a gene expression cassette for M. maripaludis and a lacZ gene for blue/white screening in E. coli have since been constructed $^{103}$. Plasmids for use in hyperthermophilic euryarchaea are similarly rare. Thus far, only shuttle vectors based on the small pGT5 plasmid of $P$. abyssi strain GE5 have been developed ${ }^{104}$. They can be stably propagated in $P$. abyssi strain GE9 (which is devoid of pGT5), as well as the crenarchaeote $S$. acidocaldarius $^{48,105,106}$, indicating that mechanisms of plasmid replication are conserved between the major archaeal phyla.

Analysis of gene expression. Few compounds have had a greater impact on microbial genetics than X-gal (5-bromo-4-chloro-3-indoyl- $\beta$-D-galactopyranoside), a chromogenic substrate that is converted by $\beta$ galactosidase into an insoluble blue dye. Originally developed by Julian Davies and Jacques Monod for studies of the lac operon of E. coli, it has since been put to 1001 uses. In archaea, as in many other organisms, it has been employed as a phenotypic reporter for gene expression (Table 3). The E. coli genes can be used directly in methanogens: $l a c Z$ has been used to monitor gene expression in M. maripaludis ${ }^{20}$ and the $\beta$-glucuronidase gene uidA has been used similarly in M. voltae and M. acetivorans ${ }^{88,107}$. However, since methanogens are strict anaerobes and oxygen is necessary for blue colour development from X-gal, replicaplating is often essential if viable cells are to be recovered; this is not necessary for $M$.maripaludis, which 
can tolerate short exposure to oxygen (J. Leigh, personal communication). While such problems are not encountered with halophiles (they are aerobic), E. coli lacZ is not active in the high salt concentrations found in the haloarchaeal cytosol (up to $5 \mathrm{M} \mathrm{KCl}$ ). The laboratory of Mike Dyall-Smith therefore isolated a $\beta$ galactosidase gene bgaH from Haloferax alicantei (now called Haloferax lucentensis) that develops a blue colour from X-gal ${ }^{108}$. Moreover, it is functional in $H$. salinarum and $H f x$. volcanii (which lacks detectable $\beta$ galactosidase activity), and has been used as a reporter gene for transcription analyses in both species ${ }^{109,110}$. A similar approach has been taken for thermophilic archaea, using a thermostable $\beta$-galactosidase from $S$. solfataricus encoded by $l a c S^{111,112}$. A mutant strain of $S$. solfataricus is available, where lacS has been inactivated by transposition of an insertion element ${ }^{113}$, and was recently used by the laboratory of Christa Schleper to develop a sophisticated gene reporter system ${ }^{83}$.

Phenotypic markers other than $\beta$-galactosidase have been used (see Table 3). For example, the salt-resistant trehalase gene treA from Bacillus subtilis is functional in M. voltae, and its activity can be assayed in cell lysates ${ }^{114}$. Recently, a modified derivative of green fluorescent protein (GFP) was developed that is soluble and active in the high salt cytosol of $H f x$. volcanii ${ }^{115}$. However, researchers are increasingly turning to ersatz genetics. Genome sequence data has led to the development of archaeal microarrays, enabling studies of the response to UV radiation in Halobacterium sp. NRC-1 ${ }^{116}$, a characterisation of the central metabolism of $H f x$. volcanii ${ }^{117}$, and the identification of chromosomal replication origins in Sulfolobus ${ }^{39}$. It is noteworthy that the latter study was only possible because the cell cycle of Sulfolobus has been studied in some detail, resulting in a variety of means for synchronising cell cultures ${ }^{118}$. No doubt further microarray studies will be published in the near future, but if researchers are to make full use of such modern technology, they must first confront basic aspects of archaeal cell biology such as the cell cycle. Without bread-and-butter genetics, we will continue to operate without a solid foundation of knowledge about these fascinating organisms. 


\section{Future directions}

Since the field was last reviewed ${ }^{19,120}$, there has been considerable progress in development of tools for archaeal genetics. Gene knock-out systems in particular have made possible the systematic dissection of pathways that operate in this domain of life (Figure 1). However, there is much work to be done. For example, S. solfataricus P1 and P2 strains stubbornly refuse to integrate foreign DNA into the chromosome by homologous recombination, thereby limiting the scope of genetics in this important organism. The way forward might be to use a different isolate of $S$. solfataricus that is proficient for recombination ${ }^{86}$. With the exception of SSV1, archaeal viruses have yet to be harnessed for genetic purposes. Gene transfer by phagemediated transduction would speed up the construction of archaeal mutant strains. Gene expression systems with tightly regulated promoters are sorely lacking. Heat-inducible chaperonin promoters are available for $H f x$. volcanii and $S$. solfataricus ${ }^{83,121}$, but the use of heat-shock to induce transcription is far from desirable. In this respect, progress is being made in $M$. acetivorans, where an acetate-inducible overexpression system has been developed (K. Sowers, personal communication). An improved method of gene regulation would also enable the development of archaeal two-hybrid systems, since yeast or bacterial two-hybrid systems are seldom of any value for analysing interactions between halophilic or thermophilic proteins. Finally, the genome sequences of several key archaea, including $H f x$. volcanii, $M$. voltae and $S$. acidocaldarius, have yet to be published (Table 1). No doubt, this will be rectified in the near future.

Above all, more researchers should be working on archaea. Neophyte "archae-ologists" can find an entertaining introduction to the subject in The Surprising Archaea by John Howland ${ }^{122}$. There are lab manuals containing detailed protocols for methanogens ${ }^{123}$, thermophiles ${ }^{124}$ and halophiles ${ }^{125}$; for the latter, the excellent "HaloHandbook" is available online (see Online Links). Above all, researchers thinking of switching to archaea (and those who are merely curious) should remember that there is no single model organism for this entire domain. The wide range of habitats colonised by archaea is testament to their diversity, which is reflected at the molecular level by the bewildering array of metabolic and energy conversion mechanisms they employ. Nevertheless, there is a core of functions related to information processing that unites and defines archaea, and it is here that they share a common heritage with eukaryotes. Exciting discoveries await those who take the third way. 


\section{Box 1 | Archaeal taxonomy and the impact of lateral gene transfer}

Archaeal taxonomy. The idea of using amino acid sequences as a tool for molecular phylogeny was first proposed by Francis Crick in $1958^{126}$, but had to wait until the molecular biology revolution of the 1970s, when Carl Woese revisited the problem of prokaryotic taxonomy ${ }^{1}$. His choice of small-subunit (SSU) ribosomal RNA sequence as a molecular chronometer was visionary ${ }^{127}$. As an essential component of all self-replicating organisms, rRNA shows remarkable sequence conservation; different parts of the molecule exhibit varying rates of base substitution, allowing both coarse and fine-scale phylogenetic analyses. Furthermore, rRNA is abundant and easy to isolate, which has proved essential to CULTIVATIONINDEPENDENT STUDIES (Box 2).

The rRNA tree (below) reveals that the domain Archaea comprises several phyla. Euryarchaeota is the most diverse group, including all known methanogens and halophiles, in addition to thermophilic and PSYCHROPHILIC species. Members of Crenarchaeota are renowned as hyperthermophiles (all temperature record-breaking species belong to this phylum), but include the psychrophile Cenarchaeum symbiosum. Of the remaining phyla, Nanoarchaeota has one known member (Nanoarchaeum equitans ${ }^{128}$ ), and to date Korarchaeota are indicated only by environmental DNA sequences ${ }^{129}$. Owing to the paucity of identified species, the positions of these phyla within the rRNA tree are uncertain (indicated by dashed branches).

Lateral gene transfer (LGT). Unfortunately, life is not as simple as the rRNA tree suggests. It is commonly assumed that only eukaryotes indulge in sex, whereas prokaryotes rely on vertical inheritance (coupled with prodigious reproductive powers) to meet new environmental challenges. In reality, prokaryotes are highly promiscuous, and the role of LGT as a driving force in prokaryotic evolution has been grossly underestimated $^{12}$. The fraction of "foreign" (mostly bacterial) genes in archaea might be as high as 20$30 \%{ }^{130}$. Most are the result of orthologous replacement or acquisition of a paralogous gene. Consequently, archaeal genomes resemble fine-scale genetic mosaics ${ }^{131}$. Occasionally, LGT can lead to a novel gain-offunction event. It has been suggested that the switch from an anaerobic to aerobic lifestyle by the (methanogenic) ancestor of haloarchaea was facilitated by LGT of respiratory chain genes from bacteria ${ }^{132}$. Archaea, like bacteria, often group co-regulated genes in operons, and this arrangement would promote coinheritance by LGT.

The degree to which archaea are "polluted" by bacterial genes depends on the species examined, and LGT might account for some variation in archaeal genome sizes (see Table 1). For example, Methanosarcina mazei has a bloated genome of $4.10 \mathrm{Mbp}, 30 \%$ of which is bacterial in origin ${ }^{133}$. Metabolically diverse methanogenic and halophilic archaea are most promiscuous, having motive, means and opportunity for LGT: their motive is to acquire genes for novel metabolic functions, the opportunity arises because methanogens and halophiles often cohabit with bacteria, and the means is their ability to engage in cell mating, as demonstrated for Haloferax volcanii ${ }^{57}$. 
LGT has serious consequences for taxonomy. Phylogenetic trees based on individual genes differ significantly from the rRNA tree ${ }^{134}$, and the notion of a "core" of never-exchanged genes has not passed muster ${ }^{131}$; such is the extent of LGT, that no one gene is unique to either archaea or bacteria. Even the gold standard of rRNA can be corrupted when multiple copies of the SSU rRNA gene are present, as in haloarchaea ${ }^{135}$. Nevertheless, as more archaeal genomes are sequenced and analysed, so a genomic signature is emerging that defines this domain in a holistic way ${ }^{14}$.

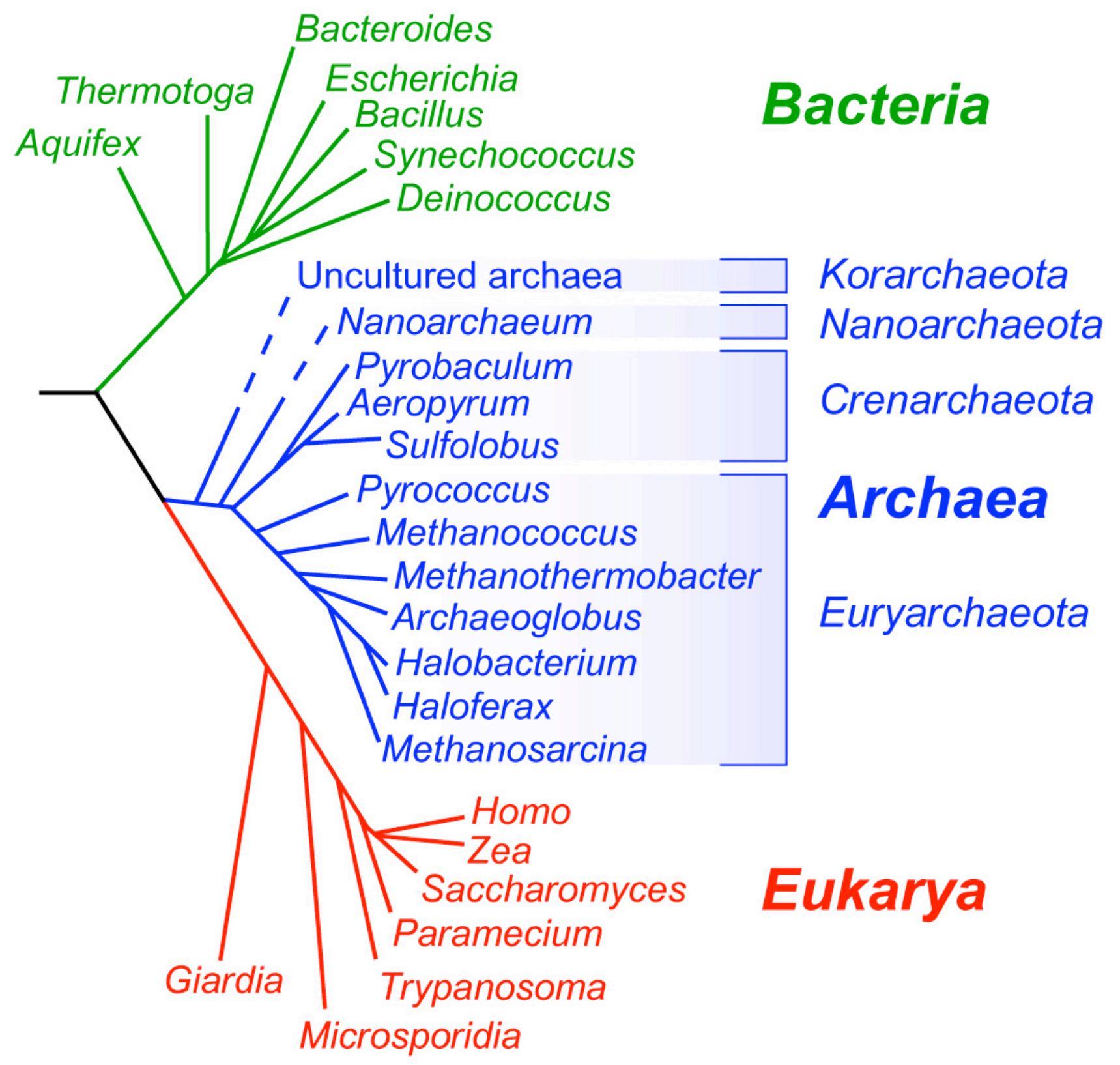




\section{Box 2 | The ecological distribution of archaea - not just extremophiles}

The archaea are notorious for inhabiting some of the most forbidding places on earth, and thrive under conditions that few bacteria and no eukaryotes would tolerate. Some of these habitats are illustrated in the figure. Methanogens are strict anaerobes that inhabit a variety of anoxic habitats such as swamps (a) and sewage plants, and have a unique ability to generate energy by reducing carbon dioxide to form methane ${ }^{136}$. This was first noted by the Italian physicist Alessandro Volta, who found that "combustible air" is produced in lakes and bogs. Halophilic archaea grow readily in hypersaline ponds (b) and salt lakes such as the Dead Sea. Unlike bacteria, which maintain an osmotic balance using organic compatible solutes such as betaine, archaea accumulate inorganic salts (mainly $\mathrm{K}^{+}$) in the cytoplasm. While this allows them to grow in saturating $\mathrm{NaCl}$ solutions, it requires that proteins of haloarchaea be adapted to function in high salt. ACIDOPHILES and ALKALIPHILES grow, as their names suggest, at extremes of $\mathrm{pH}$; acidophiles are often thermophiles and a significant fraction of alkaliphiles are also halophiles. Thermophiles such as Pyrolobus fumarii are found near deep-sea hydrothermal vents (c), where temperatures exceed $100^{\circ} \mathrm{C}$, and Sulfolobus solfataricus populates hot springs such as those in Yellowstone National Park (d). There are numerous molecular adaptations to thermophily, but the most striking is reverse gyrase, an enzyme that introduces positive supercoils in DNA and thereby protects it from unwinding ${ }^{137}$. At the opposite end of the spectrum, psychrophilic archaea thrive in permanently cold conditions such as the seawater or dry lakes in the Antarctic. However, it is misleading to believe that all archaea have been damned to such a hellish existence. Cultivation-independent methods such as ENVIRONMENTAL GENOME SHOTGUN SEQUENCING have indicated that mesophilic archaea are remarkably commonplace ${ }^{138}$ and might represent more than $20 \%$ of microbial cells in the oceans ${ }^{5}$. Thus, classical microbiology, with its emphasis on pure culture, is inadequate at determining microbial diversity.

It has been suggested that our inability to culture mesophilic archaea might account for our inability to detect pathogenic archaea ${ }^{139}$. Although indicators of archaeal population density (such as methane levels) have been found to correlate with diseases such as chronic periodontitis ${ }^{140}$, there is not one single example of an archaeon being directly responsible for a human malady. Lateral gene transfer between archaea and bacteria might have contributed to bacterial pathogenesis, where it has led to the emergence of novel virulence genes in the latter ${ }^{141}$. Although pathogenic archaea might exist, it is also possible that an intrinsic feature prevents them from posing a threat to vertebrates. For instance, archaea have unique cell membranes with isoprene side-chains ${ }^{3}$, and liposome adjuvant prepared from archaeal membranes elicit a significantly greater immune response than liposomes prepared from bacterial membranes ${ }^{142}$. Thus, an archaeal pathogen would be an easy target for the immune system. 

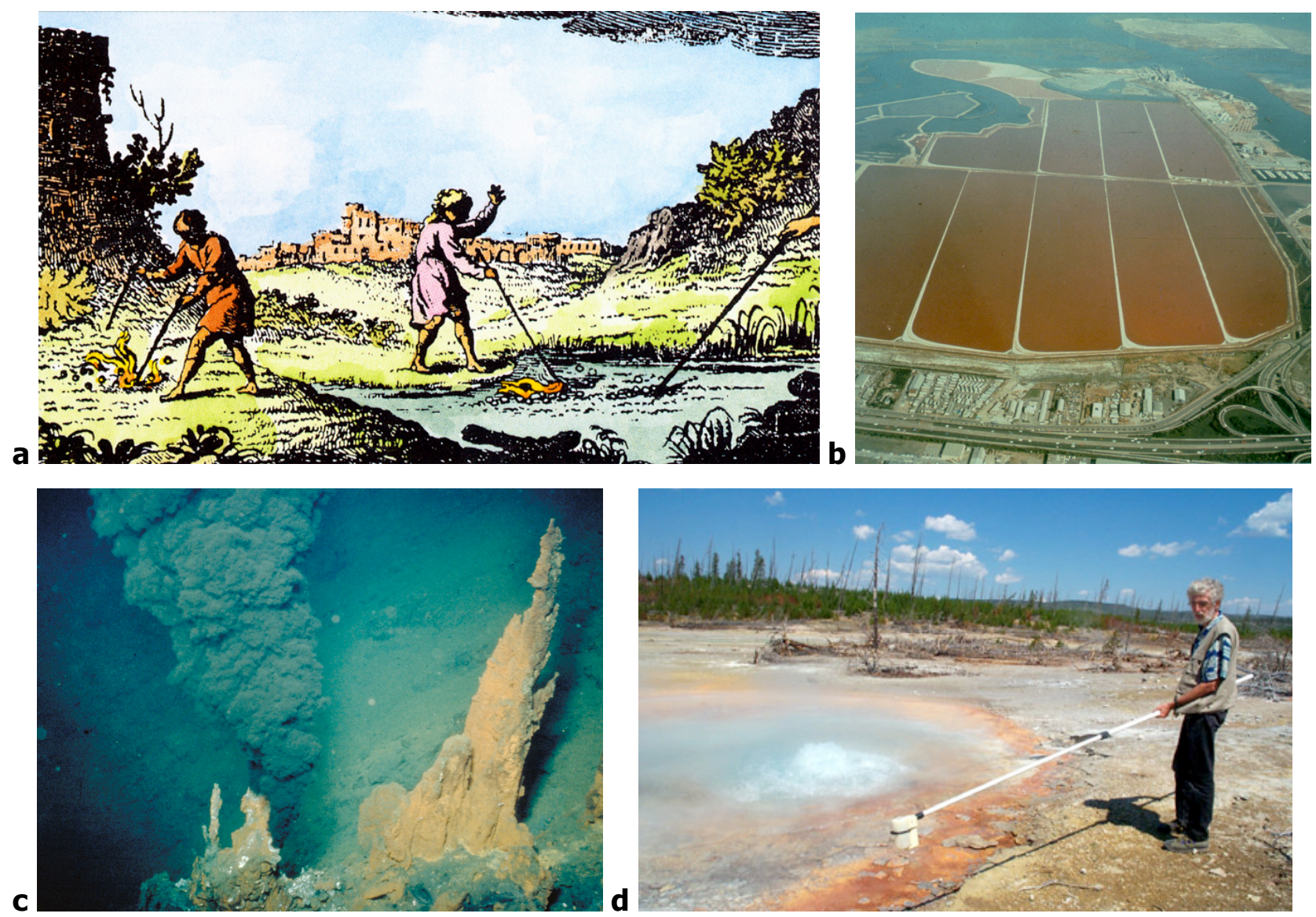

Panel A is a woodcut from the book by Alessandro Volta Lettere sull'Aria Inflammabile nativa delle Paludi, and is reproduced with permission from Cold Spring Harbor Laboratory Press; Panel B kindly provided by Richard Shand, Northern Arizona University, USA; Panel C kindly provided by Michel Gouillou, French Research Institute for the Exploitation of the Sea; Panel D kindly provided by Malcolm White, University of St Andrews, UK. 


\section{Box 3 | Genetics needs a solid (media) foundation}

The primary requirement for any genetic system is the ability to obtain clonal cultures. Robert Koch first realised the potential of solid media for pure culture methods, by noting that different colonial forms breed true and therefore represent the clonal expansion of a single cell. Thus, he laid the cornerstone for microbiology and microbial genetics. Two associates of Koch developed the necessary technology at the end of the 19th century: Richard Petri invented the eponymous dish and Walter Hesse (more accurately, his wife Fannie) adopted agar as a gelling agent. To this day, little has changed.

Archaeal genetics is no exception - growth on solid media is essential before techniques such as transformation can be developed (see Table). The culture of haloarchaea is trivial, as they are aerobic and most grow at $35-45^{\circ} \mathrm{C}$ and neutral $\mathrm{pH}$. Provided sufficient salt is present in the media, there is little to distinguish halophilic methods from those used with E. coli ${ }^{125}$. Handling methanogens is trickier, primarily because they are obligate anaerobes and require an environment with a reducing potential of less than -330 $\mathrm{mV}$. Efficient cultivation has only been possible since 1950, when the "Hungate" technique for preparing and dispensing chemically-prereduced media into stoppered tubes was introduced ${ }^{123}$. Another innovation due to Hungate was the use of roll tubes, where agar is spun horizontally to coat the inner surface of the vessel ${ }^{143}$. A refined version of the Hungate technique is still in use today ${ }^{144}$, although the introduction of the anaerobic glove box has allowed the use of conventional Petri dishes.

Gellan gum (also known as Gelrite) has been instrumental in the establishment of genetics for hyperthermophiles, which grow above the gelling temperature of agar ${ }^{124}$. Gelrite is a deacetylated polysaccharide produced by Pseudomonas elodea, and solidifies in the presence of divalent cations to form a matrix that is stable at temperatures as high as $120^{\circ} \mathrm{C}$. The major disadvantage of Gelrite is that it contains trace nucleic acids, which can interfere with selection for uracil PROTOTROPHY ${ }^{53,84}$. Transformants are therefore grown in selective liquid medium (deficient in uracil) before plating on Gelrite. However, given the importance of selection on solid media to the development of genetics, a more elegant solution will no doubt be found. 


\begin{tabular}{|c|c|c|c|}
\hline $\begin{array}{l}\text { Transformation or gene } \\
\text { transfer method }\end{array}$ & $\begin{array}{l}\text { Species } \\
\text { (see Table 1) }\end{array}$ & References & Notes \\
\hline Polyethylene glycol (PEG) & $\begin{array}{l}\text { Har Hbt Hvo } \\
\text { Mma Pab }\end{array}$ & $45,47,48,145,146$ & $\begin{array}{l}\text { Requires spheroplast formation by removal of } \\
\text { S-layer (usually by treatment with EDTA, but } \\
\text { not for Methanococcus maripaludis). }\end{array}$ \\
\hline Electroporation & $\begin{array}{l}\text { Mac Mvo } \\
\text { Sso }\end{array}$ & $49-52$ & Not universally applicable in archaea. \\
\hline Liposomes & $\begin{array}{l}\text { Mac Mba } \\
\text { Mvo }\end{array}$ & 52,114 & Very efficient, but expensive. \\
\hline $\mathrm{CaCl}_{2} \&$ heat shock & $\begin{array}{l}\text { Mvo Pfu Sac } \\
\text { Tko }\end{array}$ & $53,54,105$ & Not very efficient. \\
\hline Cell mating/conjugation & Hvo Sac & 57,59 & $\begin{array}{l}\text { Chromosomal marker exchange requires stable } \\
\text { cell contact for Haloferax volcanii, but not } \\
\text { Sulfolobus acidocaldarius. }\end{array}$ \\
\hline $\begin{array}{l}\text { Virus/plasmid-mediated } \\
\text { conjugation }\end{array}$ & Sso & $50,51,60,99,100$ & $\begin{array}{l}\text { Mediated by self-spreading vectors based on } \\
\text { SSV1 virus or pNOB } 8 \text { plasmid. }\end{array}$ \\
\hline Transduction & Mth Mvo & 55,56 & $\begin{array}{l}\text { Mth refers to Methanobacterium } \\
\text { thermoautotrophicum Marburg. }\end{array}$ \\
\hline
\end{tabular}




\section{Figure 1 | Gene knockout methods used in archaeal genetics.}

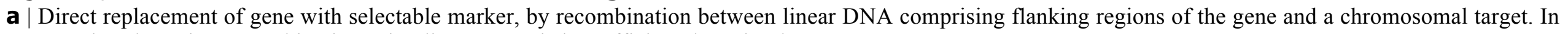
some archaeal species, recombination using linear DNA is less efficient than circular DNA.

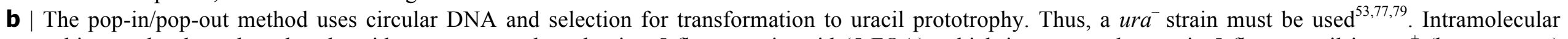

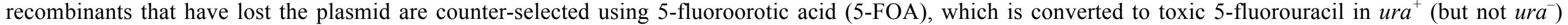
cells. Unless the mutant has a readily screened phenotype, the deletion must be verified by Southern blotting.

C Variant of the pop-in/pop-out method for gene deletion, where the gene is replaced with a marker allowing direct selection ${ }^{80}$.

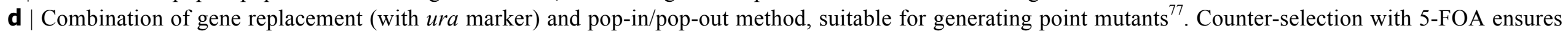
that the $u r a$-marked gene deletion is replaced with the desired mutation.

\section{Figure 2 | Plasmid vectors.}

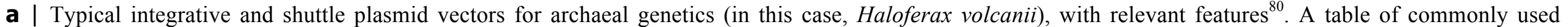
plasmids is available in the online resources.

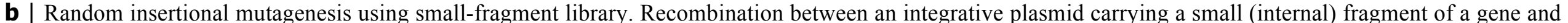

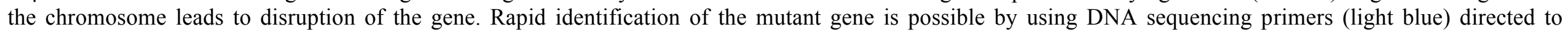

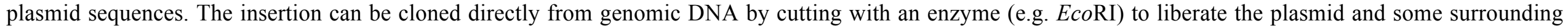
sequence, which is self-ligated and used to transform E. coli. 
a Gene replacement

b Pop-in/pop-out gene deletion

\section{c Pop-in/pop-out} gene replacement

d Two-step pop-in/pop-out gene deletion or mutation

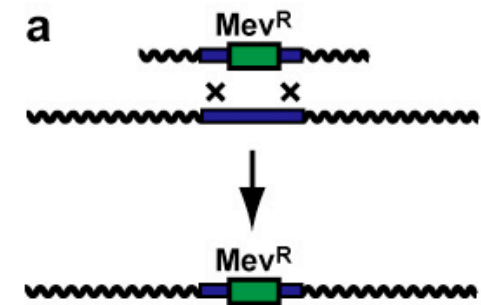

Deletion mutant b

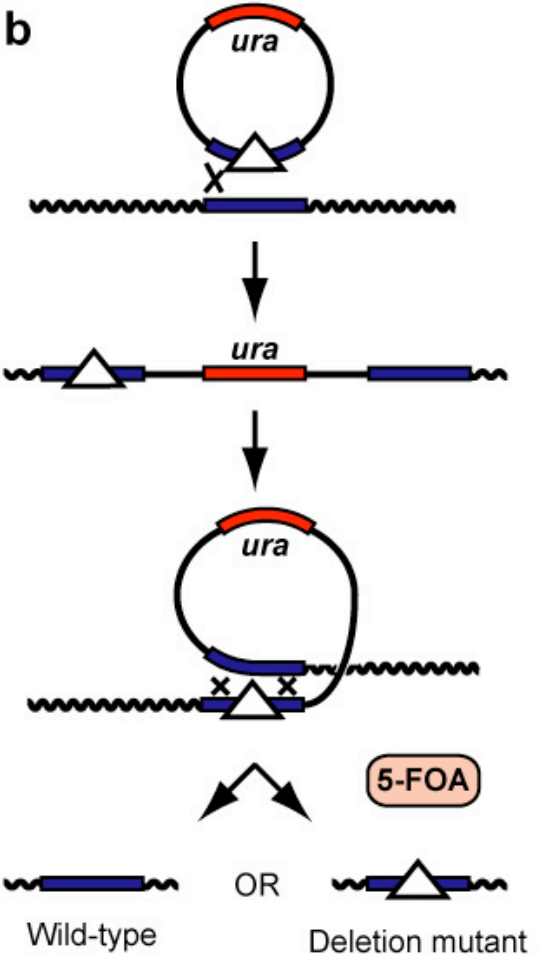

Circular DNA transformation Marker can be reused

Requires ura- strain

No direct selection
C
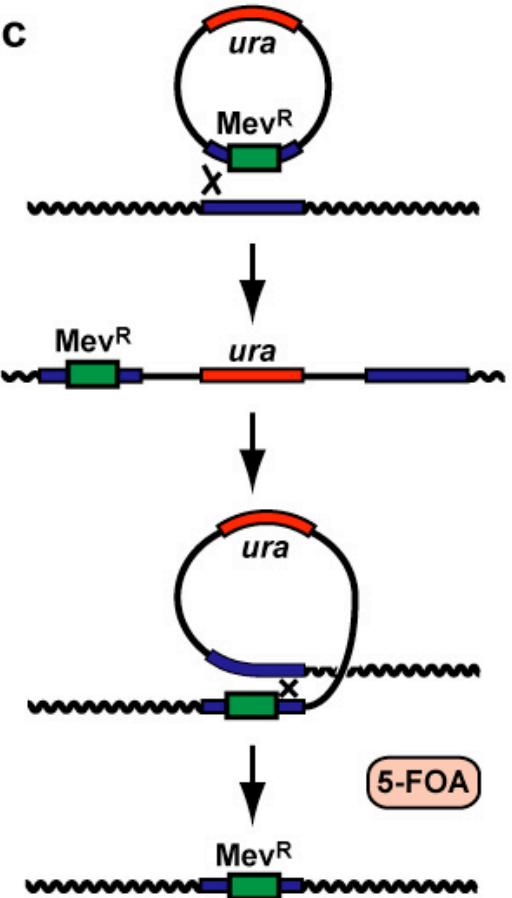

Deletion mutant

Circular DNA transformation Direct selection

Requires ura- strain

Marker cannot be reused d

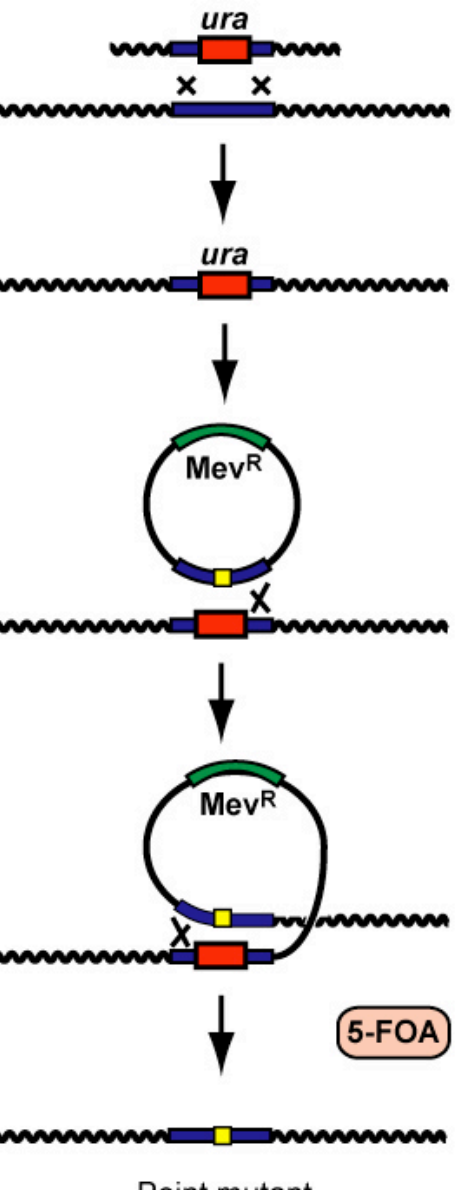

Point mutant

Direct selection

Markers can be reused

Requires ura- strain

Linear DNA transformation 
Features of integrative vector

- Selectable marker for H. volcanii (pyrE2)

- Replication origin for E. coli (ColE1 origin)

- Selectable marker for E. coli (AmpR)

- Multiple cloning site

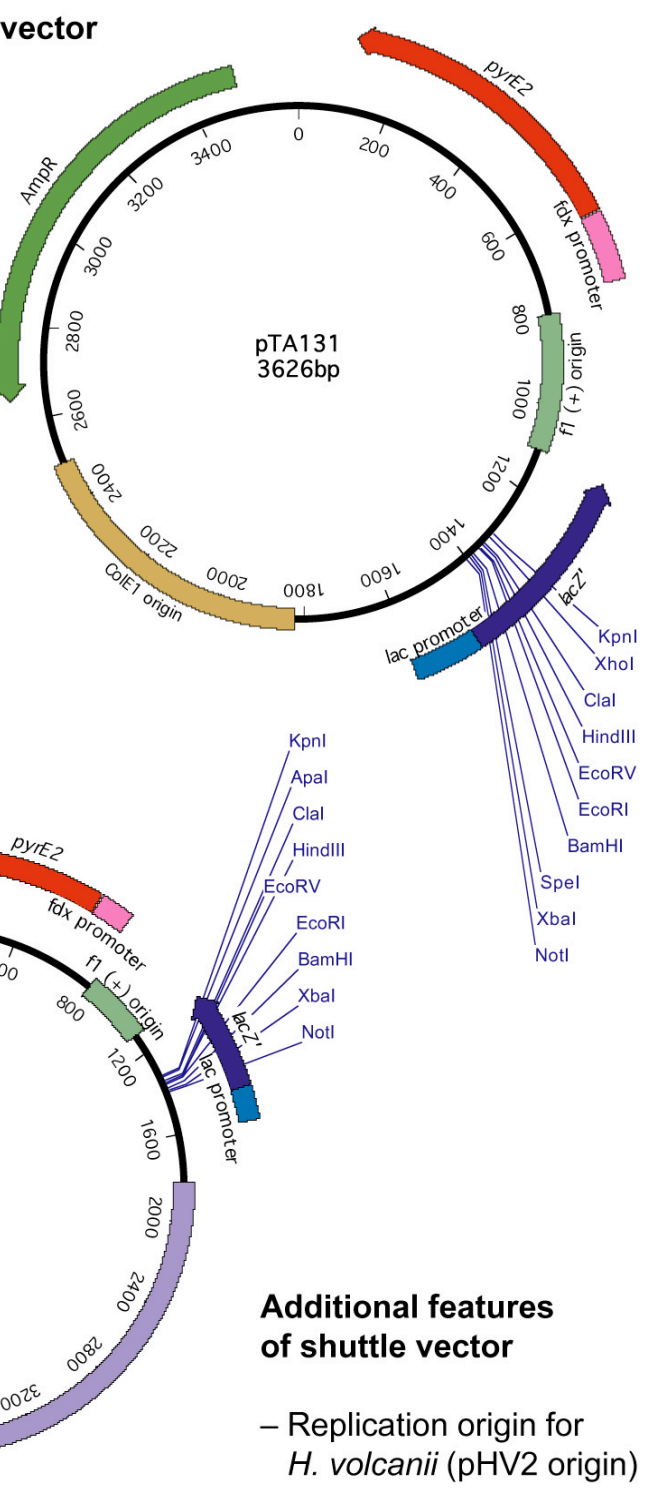

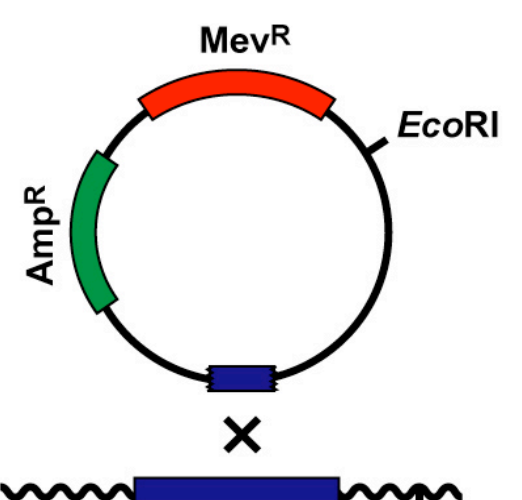

Transform

archaeal host

with small-

fragment library
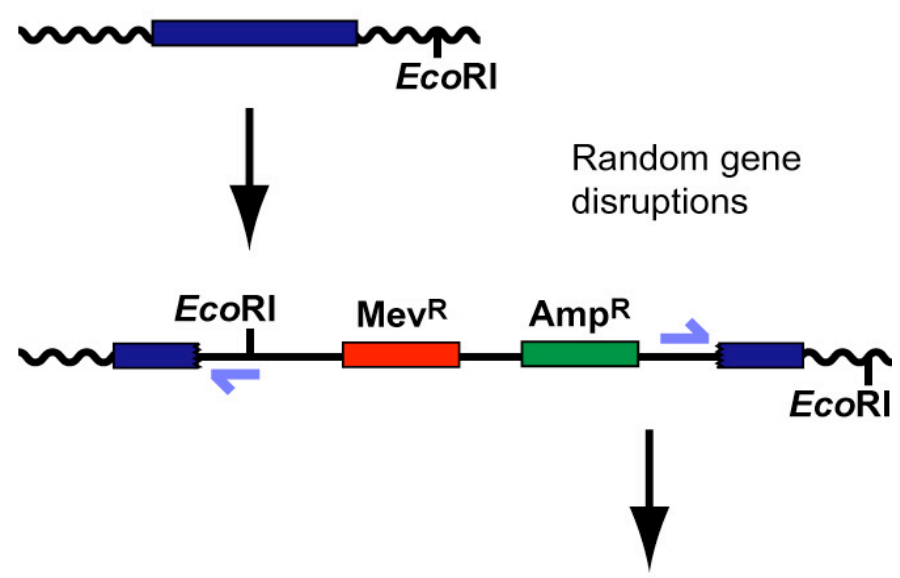

Excise plasmid and self-ligate,

transform E.coli

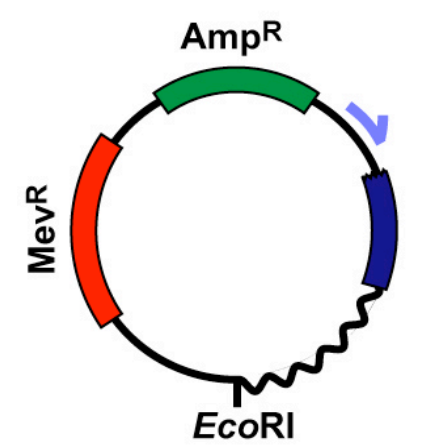




\begin{tabular}{|c|c|c|c|c|c|c|c|}
\hline Species & Abbreviation & Genome & Date & Phylum & Growth characteristics and optimal temperature & Genetics & Sequence \\
\hline Methanocaldococcus jannaschii & & 1.66 & 1996 & Eury. & Hyperthermophilic methanogen, anaerobic, $85^{\circ} \mathrm{C}$ & & NCBI \\
\hline Archaeoglobus fulgidus & & 2.18 & 1997 & Eury. & $\begin{array}{l}\text { Hyperthermophile, sulphate-reducing, anaerobic, } \\
83^{\circ} \mathrm{C}\end{array}$ & & NCBI \\
\hline Methanothermobacter & Mth & 1.75 & 1997 & Eury. & Methanogen, anaerobic, $65^{\circ} \mathrm{C}$ & + & NCBI \\
\hline thermautotrophicus & & & & & & & \\
\hline Pyrococcus horikoshii & & 1.74 & 1998 & Eury. & Hyperthermophile, anaerobic, $96^{\circ} \mathrm{C}$ & & NCBI \\
\hline Aeropyrum pernix & & 1.67 & 1999 & Cren. & Hyperthermophile, aerobic, $95^{\circ} \mathrm{C}$ & & NCBI \\
\hline Halobacterium sp. NRC-1* & $\mathrm{Hbt}$ & 2.57 & 2000 & Eury. & Halophile, aerobic, $42^{\circ} \mathrm{C}$ & +++ & NCBI \\
\hline Halobacterium salinarum* & $\mathrm{Hbt}$ & $\sim 2.5$ & $2000 \dagger$ & Eury. & Halophile, aerobic, $42^{\circ} \mathrm{C}$ & +++ & MPG \\
\hline Thermoplasma acidophilum & & 1.56 & 2000 & Eury. & Thermoacidophile, aerobic, $59^{\circ} \mathrm{C}$ & & NCBI \\
\hline Thermoplasma volcanium & & 1.58 & 2000 & Eury. & Thermoacidophile, aerobic, $60^{\circ} \mathrm{C}$ & & NCBI \\
\hline Pyrococcus abyssi & $\mathrm{Pab}$ & 1.77 & 2001 & Eury. & Hyperthermophile, anaerobic, $96^{\circ} \mathrm{C}$ & ++ & NCBI \\
\hline Pyrococcus furiosus & Pfu & 1.91 & 2001 & Eury. & Hyperthermophile, anaerobic, $96^{\circ} \mathrm{C}$ & ++ & NCBI \\
\hline Pyrolobus fumarii & & 1.85 & $2001 \dagger$ & Cren. & Hyperthermophile, aerobic $106^{\circ} \mathrm{C}$ & & \\
\hline Sulfolobus solfataricus & Sso & 2.99 & 2001 & Cren. & Thermoacidophile, aerobic, $80^{\circ} \mathrm{C}$ & +++ & NCBI \\
\hline Sulfolobus tokodaii & & 2.69 & 2001 & Cren. & Thermoacidophile, aerobic, $80^{\circ} \mathrm{C}$ & + & NCBI \\
\hline Ferroplasma acidarmanus & & 1.87 & $2002 \S$ & Eury. & Acidophile, anaerobic, $42^{\circ} \mathrm{C}$ & & ORNL \\
\hline Methanopyrus kandleri & & 1.69 & 2002 & Eury. & Hyperthermophilic methanogen, anaerobic, $98^{\circ} \mathrm{C}$ & & NCBI \\
\hline Methanosarcina acetivorans & Mac & 5.75 & 2002 & Eury. & Methanogen, anaerobic, $35^{\circ} \mathrm{C}$ & +++ & NCBI \\
\hline Methanosarcina barkeri & Mba & 4.86 & $2002 \S$ & Eury. & Methanogen, anaerobic, $35^{\circ} \mathrm{C}$ & +++ & ORNL \\
\hline Methanosarcina mazei & $\mathrm{Mmz}$ & 4.10 & 2002 & Eury. & Methanogen, anaerobic, $37^{\circ} \mathrm{C}$ & +++ & NCBI \\
\hline Pyrobaculum aerophilum & & 2.22 & 2002 & Cren. & Hyperthermophile, nitrate-reducing, aerobic, $100^{\circ} \mathrm{C}$ & & NCBI \\
\hline Hyperthermus butylicus & & 1.67 & $2003 \dagger$ & Cren. & $\begin{array}{l}\text { Hyperthermophile, sulphate-reducing, anaerobic, } \\
100^{\circ} \mathrm{C}\end{array}$ & & \\
\hline Methanogenium frigidum & & $\sim 2.5$ & $2003 \S$ & Eury. & Psychrophilic methanogen, anaerobic, $15^{\circ} \mathrm{C}$ & & UNSW \\
\hline Nanoarchaeum equitans & & 0.49 & 2003 & Nano. & Symbiotic hyperthermophile, anaerobic, $90^{\circ} \mathrm{C}$ & & NCBI \\
\hline Sulfolobus acidocaldarius & $\mathrm{Sac}$ & 2.23 & $2003 \dagger$ & Cren. & Thermoacidophile, aerobic, $80^{\circ} \mathrm{C}$ & ++ & \\
\hline Haloarcula marismortui & Har & 4.27 & 2004 & Eury. & Halophile, aerobic, $37^{\circ} \mathrm{C}$ & + & NCBI \\
\hline Haloferax volcanii & Hvo & 4.03 & $2004 \uparrow$ & Eury. & Halophile, aerobic, $45^{\circ} \mathrm{C}$ & +++ & $\begin{array}{l}\text { UMBI; } \\
\text { TIGR }\end{array}$ \\
\hline Methanococcoides burtonii & & 2.56 & $2004 \S$ & Eury. & Psychrotolerant methanogen, anaerobic, $23^{\circ} \mathrm{C}$ & & ORNL \\
\hline Methanococcus maripaludis & Mma & 1.66 & 2004 & Eury. & Methanogen, anaerobic, $37^{\circ} \mathrm{C}$ & +++ & NCBI \\
\hline Methanococcus voltae & Mvo & $\sim 1.9$ & $2004 \dagger$ & Eury. & Methanogen, anaerobic, $37^{\circ} \mathrm{C}$ & +++ & \\
\hline Natronomonas pharaonis & & 2.75 & $2004 \uparrow$ & Eury. & Haloalkaliphile, aerobic, $40^{\circ} \mathrm{C}$ & & \\
\hline Picrophilus torridus & & 1.55 & 2004 & Eury. & Acidophile, aerobic, $60^{\circ} \mathrm{C}$ & & NCBI \\
\hline Thermococcus kodakaraensis & Tko & 2.09 & $2004 \dagger$ & Eury. & Hyperthermophile, anaerobic, $85^{\circ} \mathrm{C}$ & ++ & \\
\hline
\end{tabular}




\begin{tabular}{|c|c|c|c|c|c|c|}
\hline Thermoproteus tenax & $\sim 1.84$ & $2004 \S$ & Cren. & Hyperthermophile, anaerobic, $86^{\circ} \mathrm{C}$ & & 44 \\
\hline Acidianus brierleyi & $\sim 1.9$ & & Cren. & Thermoacidophile, aerobic, $70^{\circ} \mathrm{C}$ & & \\
\hline Halobaculum gomorrense & $\sim 2.7$ & & Eury. & Halophile, aerobic, $37^{\circ} \mathrm{C}$ & + & \\
\hline Haloquadratum walsbyi & $\sim 3.18$ & & Eury. & Halophile, aerobic, $40^{\circ} \mathrm{C}$ & & \\
\hline Halorubrum lacusprofundi & $\sim 2.6$ & & Eury. & Psychrotolerant halophile, aerobic, $30^{\circ} \mathrm{C}$ & + & \\
\hline Natrialba asiatica & $\sim 3.1$ & & Eury. & Halophile, aerobic, $37^{\circ} \mathrm{C}$ & + & \\
\hline Sulfolobus metallicus & $\sim 1.9$ & & Cren. & Thermoacidophile, aerobic, $80^{\circ} \mathrm{C}$ & & \\
\hline Cenarchaeum symbiosum & & & Cren. & Symbiotic psychrophile, aerobic, $10^{\circ} \mathrm{C}$ & & \\
\hline Methanococcus & & & Eury. & Thermophilic halotolerant methanogen, anaerobic, & & \\
\hline thermolithotrophicus & & & & $62^{\circ} \mathrm{C}$ & & \\
\hline Methanosaeta concilii & & & Eury. & Methanogen, anaerobic, $37^{\circ} \mathrm{C}$ & & \\
\hline Methanosarcina thermophila & & & Eury. & Thermophilic methanogen, anaerobic, $50^{\circ} \mathrm{C}$ & & \\
\hline Methanosphaera stadtmanae & & & Eury. & Methanogen, anaerobic, $37^{\circ} \mathrm{C}$ & & \\
\hline Methanospirillum hungateii & & & Eury. & Methanogen, anaerobic, $37^{\circ} \mathrm{C}$ & & \\
\hline
\end{tabular}

Table 1 | Archaea with sequenced genomes or ongoing genome projects.

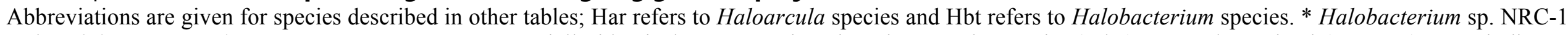

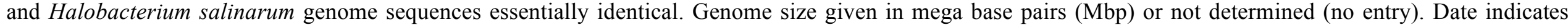

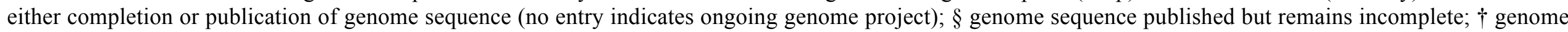

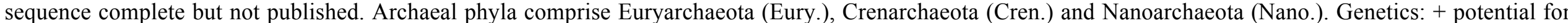

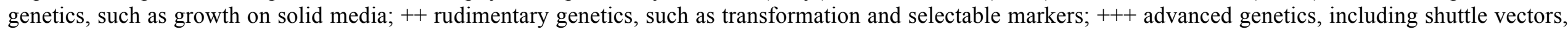
gene replacement, reporter genes. Where possible, websites hosting genome sequence data are given; for abbreviations and URLs see Online Links. 


\begin{tabular}{|c|c|c|c|c|c|}
\hline Selection & Type & Marker & Species & References & Notes \\
\hline $\begin{array}{l}\text { Alcohol dehydrogenase } \\
\text { Anisomycin }\end{array}$ & $\begin{array}{l}\text { A } \\
\text { A }\end{array}$ & $\begin{array}{l}\text { adh, } a d h-h T \\
\text { Ani }^{\mathrm{R}} \\
(23 \mathrm{~S} \text { rRNA) }\end{array}$ & $\begin{array}{l}\text { Pfu Sso } \\
\mathrm{Hbt}\end{array}$ & $\begin{array}{l}106,147 \\
148\end{array}$ & $\begin{array}{l}\text { Alcohol dehydrogenase adh-hT gene from Bacillus stearothermophilus. } \\
\text { Mutant 23S rRNA gene, used for mutation of chromosomal rRNA gene } \\
\text { but not developed as selectable marker }\end{array}$ \\
\hline Bleomycin & A & ShBle & Hvo & 149 & Bleomycin-resistance ShBle gene from Streptoalloteichus hindustanus \\
\hline Hygromycin B & A & $h p h$ & Sso & 51,150 & $\begin{array}{l}\text { Mutated (thermostable) version of the hygromycin B } \\
\text { phosphotransferase }(h p h(m u t)) \text { gene from Escherichia coli. }\end{array}$ \\
\hline Mevinolin & A & $\operatorname{Mev}^{\mathrm{R}}(h m g)$ & Har Hbt Hvo & $63,72,73,145$ & $\begin{array}{l}\text { Use of heterologous MevR gene prevents recombination between } \\
\text { chromosomal } h m g \text { gene and } \mathrm{Mev}^{\mathrm{R}} \text {. }\end{array}$ \\
\hline Neomycin & A & $\mathrm{Neo}^{\mathrm{R}}\left(\mathrm{APH} 3^{\prime}\right)$ & Mma & 70 & Geneticin not inhibitory to Methanococcus maripaludis. \\
\hline Novobiocin & A & $\operatorname{Nov}^{\mathrm{R}}(\operatorname{gyr} B)$ & Hvo Sac & & Inhibits DNA gyrase, NovR over-expresses DNA gyrase B subunit. \\
\hline Pseudomonic acid & A & $\mathrm{PA}^{\mathrm{R}}($ ileS $)$ & Mba Mac Mth & 71,151 & $\begin{array}{l}\text { Mutant isoleucyl-tRNA synthetase ileS gene from Methanosarcina } \\
\text { barkeri Fusaro. Pseudomonic acid not commercially available. }\end{array}$ \\
\hline Puromycin & A & $\operatorname{Pur}^{\mathrm{R}}(p a c)$ & $\begin{array}{l}\text { Mac Mba Mma } \\
\text { Mmz Mvo }\end{array}$ & $52,69,97,152,153$ & $\begin{array}{l}\text { Puromycin-resistance pac gene from Streptomyces alboniger, widely } \\
\text { used marker for methanogenic archaea. }\end{array}$ \\
\hline Thiostrepton & A & $\begin{array}{l}\operatorname{Ths}^{\mathrm{R}} \\
(23 \mathrm{~S} \text { rRNA) }\end{array}$ & $\mathrm{Hbt}$ & 148 & $\begin{array}{l}\text { Mutant 23S rRNA gene, used for mutation of chromosomal rRNA gene } \\
\text { but not developed as selectable marker }\end{array}$ \\
\hline Trimethoprim & A & $h d r A$ & Hvo & 154 & Trimethoprim not widely used as selectable marker. \\
\hline $\begin{array}{l}\text { 8-aza-2,6-diaminopurine (8ADP) } \\
\text { or 8-aza-hypoxanthine }\end{array}$ & $\mathrm{C}$ & hpt & Mac Mma & 88, & $\begin{array}{l}\text { Used in conjunction with puromycin or neomycin as positive selectable } \\
\text { marker. }\end{array}$ \\
\hline $\begin{array}{l}\text { Uracil/5-fluoroorotic acid } \\
\text { (5-FOA) }\end{array}$ & $\mathrm{X} / \mathrm{C}$ & $\begin{array}{l}\text { ura3, pyrE, } \\
\text { pyrF }\end{array}$ & $\begin{array}{l}\text { Hbt Hvo Pab } \\
\text { Sso Tko }\end{array}$ & $\begin{array}{l}48,53,77,79- \\
81,83,84\end{array}$ & $\begin{array}{l}\text { Very useful marker. Isolation of spontaneous } 5 \text {-FOA-resistant mutants } \\
\text { easy, allowing system to be implemented widely }{ }^{53,82,84}\end{array}$ \\
\hline Histidine & $\mathrm{X}$ & his $A$, his-1 & Mvo Hvo & 155,156 & his-1 gene of Haloferax volcanii not developed as marker. \\
\hline Lactose & $\mathrm{X}$ & $\operatorname{lacS}(+\operatorname{lacTr})$ & Sso & 86 & lacS gene in host strain disrupted by transposon or deleted. \\
\hline Leucine & $\mathrm{X}$ & lеив, ІеиA & Hvo Mma & & $\begin{array}{l}\text { leuB and leuA genes in host strains deleted. M. maripaludis leuA not } \\
\text { yet developed as marker. }\end{array}$ \\
\hline Proline & $\mathrm{X}$ & proC & Mac & & E. coli pro $C$ gene also functions as marker. \\
\hline Thymidine & $\mathrm{X}$ & $h d r A, h d r B$ & Hvo & 80,154 & $\begin{array}{l}h d r B \text { gene in host strain deleted. Complex media based on yeast extract } \\
\text { are deficient in thymidine. }\end{array}$ \\
\hline Tryptophan & $\mathrm{X}$ & $\operatorname{trp} A, \operatorname{trp} E$ & Hvo Tko & 53,80 & $\begin{array}{l}\text { trpE mutants (tryptophan auxotrophs) of Thermococcus kodakaraensis } \\
\text { isolated, but no selectable marker developed. }\end{array}$ \\
\hline
\end{tabular}

Table 2 | Selectable markers used in archaeal genetics.

Selectable marker type: antibiotic (A); counter-selectable (C); auxotrophic or similar (X). Species abbreviations, see Table 1. In this table, Mth refers to Methanobacterium thermoautotrophicum Marburg. 


\begin{tabular}{|c|c|c|c|c|}
\hline Reporter & Host & Type & References & Notes \\
\hline bgaH & $\begin{array}{l}\text { Hbt } \\
\text { Hvo }\end{array}$ & $\begin{array}{l}\text { Colour } \\
\text { (X-gal) }\end{array}$ & & $\beta$-galactosidase from Haloferax alicantei. Wild-type Haloferax volcanii lacks detectable $\beta$-galactosidase activity. \\
\hline lacS & Sso & $\begin{array}{l}\text { Colour } \\
\text { (X-gal) }\end{array}$ & $83,111-113$ & Thermostable $\beta$-galactosidase from Sulfolobus solfataricus. \\
\hline lac $Z$ & Mma & $\begin{array}{l}\text { Colour } \\
(\mathrm{X} \text {-gal) }\end{array}$ & & lac $Z$ gene from $E$. coli. Colour development requires exposure to oxygen. \\
\hline uidA & $\begin{array}{l}\text { Mac } \\
\text { Mvo }\end{array}$ & $\begin{array}{l}\text { Colour } \\
\text { (X-gluc) }\end{array}$ & 88,107 & uidA gene from E. coli. Colour development requires exposure to oxygen. \\
\hline $\begin{array}{l}\text { treA } \\
\text { GFP }\end{array}$ & $\begin{array}{l}\text { Mvo } \\
\text { Hvo }\end{array}$ & $\begin{array}{l}\text { Enz. } \\
\text { Fluor. }\end{array}$ & $\begin{array}{l}114 \\
115\end{array}$ & $\begin{array}{l}\text { Trehalase gene treA from Bacillus subtilis, enzyme insensitive to moderate salinity. } \\
\text { Modified variant of green fluorescent protein (GFP), soluble in } H f x \text {. volcanii due to reduced hydrophobicity. }\end{array}$ \\
\hline$h d r A$ & Hvo & Res. & 157 & $\begin{array}{l}\text { Ferredoxin }(f d x) \text { promoter of } H \text {. salinarum analysed in } H f x \text {. volcanii using trimethoprim. Dihydrofolate reductase } \\
(h d r A) \text { is competitively inhibited by trimethoprim. }\end{array}$ \\
\hline
\end{tabular}

Table 3 | Phenotypic markers and reporter genes used in archaeal genetics.

Species abbreviations, see Table 1. Marker types: blue colouration upon exposure to chromogenic indicator (Colour), 5-bromo-4-chloro-3-indoyl- $\beta$-Dgalactopyranoside (X-gal) or 5-bromo-4-chloro-3-indoyl- $\beta$-D-glucuronide (X-gluc); enzymatic assay from cell lysate (Enz.); fluorescent reporter protein (Fluor.); resistance to antibiotic (Res.). 


\section{Acknowledgements}

We thank Steve Bell, John Leigh, Kevin Sowers, Ed Bolt and numerous other colleagues whose comments have improved the manuscript. We are grateful to John Leigh, Bill Metcalf, Kevin Sowers, Tadayuki Imanaka, David Walsh, Steve Bell, James Chong, Alan Majernik, Friedhelm Pfeiffer, Dieter Oesterhelt and Julie Maupin-Furlow for communicating results prior to publication, and to Malcolm White, Patrick Forterre, Richard Shand, Joel Querellou, Michel Gouillou, Frank Robb and Cold Spring Harbor Laboratory Press for pictures of archaeal habitats. T.A. is supported by a Royal Society University Research Fellowship.

\section{Competing interests statement}

The authors declare that they have no competing financial interests.

\section{Autobiographies}

Thorsten Allers has a long-standing interest in genetic recombination. He received his $\mathrm{PhD}$ training in the lab of David Leach at the Institute of Cell and Molecular Biology in Edinburgh, UK, where he became acquainted with Escherichia coli. His post-doctoral work was in the laboratory of Michael Lichten at the National Cancer Institute in Maryland, USA, where he trained in genetics of Saccharomyces cerevisiae. After switching domain for the third time, he joined the Institute of Genetics in Nottingham, UK. His lab uses Haloferax volcanii to study DNA recombination and repair in archaea. For more information on the author visit http://www.nottingham.ac.uk/genetics/allers

Moshe Mevarech received his Ph.D. training in the lab of Henryk Eisenberg at the Polymer Department in the Weizmann Institute of Science, Rehovot, Israel. He did his post-doctoral training first with Kan L. Agarwal and then with Robert Haselkorn at the University of Chicago before taking a faculty position at the Department of Molecular Microbiology and Biotechnology in Tel-Aviv University, Israel. For many years, the interests of his lab have focused on applying genetic and biochemical approaches to study halophilic archaea.

\section{Online summary}

- Archaea comprise the third domain of life, alongside bacteria and eukaryotes. The domain Archaea was proposed in 1977 by Carl Woese, as a result of phylogenetic studies using ribosomal RNA sequences as a molecular chronometer.

- Archaea are renowned as extremophiles, but environmental studies suggest that they thrive in all habitats. However, to date no pathogenic archaea have been found.

- Bacteria and archaea share a prokaryotic morphology, and have comparable pathways for central metabolism and energy conversion. On the other hand, information processing pathways in archaea and eukaryotes use similar enzymes. However, the archaeal systems are much simpler.

- Lateral gene transfer between archaea and bacteria is common, and might be responsible for some evolutionary innovations.

- As much as $50 \%$ of the genes found in archaeal genomes might encode novel proteins with no obvious counterparts in bacteria or eukaryotes.

- Archaeal proteins have proved invaluable to biochemists and structural biologists, but genetic studies of archaea are still comparatively rare.

- Genetic techniques for archaea are more advanced than is commonly believed. A wide range of archaeal species can be transformed using integrative and shuttle vectors, carrying a variety of selectable markers. Methods for mutagenesis and gene knock-out are available, as are reporter genes such as $\beta$-galactosidase. 


\section{Glossary}

ACIDOPHILE

Organism that requires a low $\mathrm{pH}$ for growth, typically less than $\mathrm{pH}$ 3. Contrast with alkaliphile.

ALKALIPHILE

Organism that requires a high $\mathrm{pH}$ for growth, typically greater than $\mathrm{pH} 10$. Contrast with acidophile.

AUTOTROPH

Organism that can synthesise its own macromolecules from simple, inorganic molecules such as carbon dioxide, hydrogen and ammonia. Contrast with heterotroph.

AUXOTROPH

Mutant that requires nutrients not needed by wild-type strains for growth on minimal medium. Contrast with prototroph.

\section{COUNTER-SELECTABLE MARKER}

A marker which if present leads to cell death under selective conditions, usually by conferring sensitivity to an antibiotic or by promoting the synthesis of a toxic product from a non-toxic precursor.

\section{CULTIVATION-INDEPENDENT STUDY}

Method for determining environmental biodiversity without the need to obtain microbiologically-pure cultures, using sequences retrieved from environmental samples to construct a molecular phylogenetic survey. For example, environmental genome shotgun sequencing.

DOMAIN

Highest level of taxonomic division, comprising Archaea, Bacteria and Eukarya. In declining order, other levels include: kingdom, phylum, class, order, family, genus, and species.

\section{ENVIRONMENTAL GENOME SHOTGUN SEQUENCING}

High-throughput sequencing and computational reconstruction of genomic DNA fragments extracted from environmental samples, in order to assess microbial diversity in a cultivation-independent manner.

\section{EXTREMOPHILE}

Organism that requires extreme environments for growth, such as extremes of temperature, salinity or $\mathrm{pH}$, or a combination thereof.

HALOPHILE

Organism that requires high concentrations of salt for growth, typically greater than $1 \mathrm{M} \mathrm{NaCl}$.

HETEROTROPH

Organism that requires complex organic molecules such as amino acids and sugars, from which to build macromolecules and derive energy. Contrast with autotroph.

HYPERTHERMOPHILE

Organism that requires extremely high temperatures for growth, typically greater than $80^{\circ} \mathrm{C}$. Compare with thermophile.

\section{INTEGRATIVE VECTOR}

Plasmid vector incapable of replication in archaeal host, which therefore must integrate into the host chromosome by homologous or site-specific recombination. Contrast with shuttle vector.

\section{LATERAL GENE TRANSFER}

Horizontal transfer of genes between unrelated species, as opposed to vertical inheritance within a species.

METHANOGEN

Anaerobic organism that generates methane by reduction of carbon dioxide, a variety of one-carbon compounds or acetic acid.

\section{MONOPHYLETIC}

A natural taxonomic group consisting of species that share a common ancestor.

\section{PROTOTROPH}

Organism capable of growth on minimal medium containing a carbon source and inorganic compounds.

Contrast with auxotroph. 


\section{PSYCHROPHILE}

Organism capable of growth at permanently low temperatures, typically less than $10^{\circ} \mathrm{C}$. Contrast with thermophile.

\section{SPHEROPLAST}

Cell denuded of the vast majority of its cell wall or surface layer, usually by chemical or enzymatic treatment. Also known as protoplast.

\section{SHUTTLE VECTOR}

Plasmid vector capable of replication in both Escherichia coli and archaeal host. Contrast with integrative vector.

\section{THERMOPHILE}

Organism that requires high temperatures for growth, typically greater than $60^{\circ} \mathrm{C}$. Contrast with psychrophile.

\section{TRANSDUCTION}

Transfer of host genes between archaeal or bacterial species, using a virus as a vector.

TRANSFECTION

Infection of a host cell by naked DNA or RNA isolated from a virus.

\section{Online links}

\section{Genome sequence data}

Archaeal genomes at National Center for Biotechnology Information (NCBI): http://www.ncbi.nlm.nih.gov/genomes/static/a g.html

Halobacterium salinarum genome at Max Planck Gesellschaft (MPG): http://www.halolex.mpg.de/

Draft Haloferax volcanii genome at The Institute for Genomic Research (TIGR): http://tigrblast.tigr.org/ufmg/index.cgi?database $=\mathrm{h} \_$volcanii|seq

Halophile genomes at University of Maryland Biotechnology Institute (UMBI): http://zdna2.umbi.umd.edu/ haloweb/

Draft archaeal genomes at Oak Ridge National Laboratory (ORNL): http://genome.ornl.gov/microbial/

Draft genomes of psychrophilic archaea at University of New South Wales (UNSW):

http://psychro.bioinformatics.unsw.edu.au/genomes/

Genomes OnLine Database (GOLD): http://www.genomesonline.org/

\section{Strain repositories}

Deutsche Sammlung von Mikroorganismen und Zellkulturen GmbH (DSMZ): http://www.dsmz.de/

National Collections of Industrial, Food and Marine Bacteria (NCIMB): http://www.ncimb.co.uk/

American Type Culture Collection (ATCC): http://www.atcc.org/

Japan Collection of Microorganisms: http://www.jcm.riken.go.jp/

\section{Others}

HaloHandbook: http://www.microbiol.unimelb.edu.au/micro/staff/mds/HaloHandbook/

Gordon Research Conference (GRC) on Archaea: Ecology, Metabolism \& Molecular Biology: http://www.grc.org/programs/2005/archaea.htm 


\section{References}

1. Woese, C. R. \& Fox, G. E. Phylogenetic structure of the prokaryotic domain: the primary kingdoms. Proc Natl Acad Sci U S A 74, 5088-90 (1977).

2. Woese, C. R., Kandler, O. \& Wheelis, M. L. Towards a natural system of organisms: proposal for the domains Archaea, Bacteria, and Eucarya. Proc Natl Acad Sci U S A 87, 4576-9 (1990).

Along with reference 1 , this is the seminal paper about archaea. Woese and colleagues use phylogenetic analysis based on rRNA sequences to propose a three-domain system for living organisms.

3. van de Vossenberg, J. L., Driessen, A. J. \& Konings, W. N. The essence of being extremophilic: the role of the unique archaeal membrane lipids. Extremophiles 2, 163-70 (1998).

4. White, M. F. \& Bell, S. D. Holding it together: chromatin in the Archaea. Trends Genet 18, 621-6 (2002).

5. DeLong, E. F. \& Pace, N. R. Environmental diversity of bacteria and archaea. Syst Bio/ 50, 470-8 (2001).

6. Grabowski, B. \& Kelman, Z. Archaeal DNA replication: eukaryal proteins in a bacterial context. Annu Rev Microbiol 57, 487-516 (2003).

7. Ban, N., Nissen, P., Hansen, J., Moore, P. B. \& Steitz, T. A. The complete atomic structure of the large ribosomal subunit at $2.4 \AA$ resolution. Science 289, 905-20 (2000).

Archaeal proteins are often used for structural studies, due to their high rigidity. This paper is an impressive example, and describes the structure of the Haloarcula marismortui 505 ribosomal subunit.

8. Shin, D. S. et al. Full-length archaeal Rad51 structure and mutants: mechanisms for RAD51 assembly and control by BRCA2. EMBO J 22, 4566-76 (2003).

9. van den Burg, B. Extremophiles as a source for novel enzymes. Curr Opin Microbiol 6, $213-8$ (2003).

10. Bult, C. J. et al. Complete genome sequence of the methanogenic archaeon, Methanococcus jannaschii. Science 273, 1058-73 (1996).

11. Rivera, M. C., Jain, R., Moore, J. E. \& Lake, J. A. Genomic evidence for two functionally distinct gene classes. Proc Natl Acad Sci U S A 95, 6239-44 (1998).

12. Boucher, Y. et al. Lateral gene transfer and the origins of prokaryotic groups. Annu Rev Genet 37, $283-328$ (2003).

This is a comprehensive and up-to-date review of the breadth and depth of lateral gene transfer.

13. Jain, R., Rivera, M. C. \& Lake, J. A. Horizontal gene transfer among genomes: the complexity hypothesis. Proc Natl Acad Sci U S A 96, 3801-6 (1999).

This paper, together with reference 11, helps to explain why archaea are a mosaic of bacterial and eukaryotic features, and why genes encoding the latter are not subject to lateral gene transfer.

14. Graham, D. E., Overbeek, R., Olsen, G. J. \& Woese, C. R. An archaeal genomic signature. Proc Natl Acad Sci U S A 97, 3304-8 (2000).

By comparing several complete genome sequences, this study seeks to eliminate the background noise generated by lateral gene transfer, and derives a set of signature genes that defines the archaea in an holistic manner.

15. Huet, J., Schnabel, R., Sentenac, A. \& Zillig, W. Archaebacteria and eukaryotes possess DNA-dependent RNA polymerases of a common type. EMBO J 2, 1291-4 (1983).

In this study, Zillig and colleagues demonstrate for the first time that information processing in archaea uses enzymes similar to those found in eukaryotes.

16. Bell, S. D. \& Jackson, S. P. Mechanism and regulation of transcription in archaea. Curr Opin Microbio/ 4, 208-13 (2001).

17. Thompson, D. K., Palmer, J. R. \& Daniels, C. J. Expression and heat-responsive regulation of a TFIIB homologue from the archaeon Haloferax volcanii. Mol Microbiol 33, 1081-92 (1999).

18. Aravind, L. \& Koonin, E. V. DNA-binding proteins and evolution of transcription regulation in the archaea. Nucleic Acids Res 27, 4658-70 (1999).

19. Bell, S. D., Cairns, S. S., Robson, R. L. \& Jackson, S. P. Transcriptional regulation of an archaeal operon in vivo and in vitro. Mol Cell 4, 971-82 (1999).

20. Cohen-Kupiec, R., Blank, C. \& Leigh, J. A. Transcriptional regulation in Archaea: in vivo demonstration of a repressor binding site in a methanogen. Proc Natl Acad Sci U S A 94, 1316-20 (1997).

21. Hofacker, A., Schmitz, K. M., Cichonczyk, A., Sartorius-Neef, S. \& Pfeifer, F. GvpE- and GvpD-mediated transcription regulation of the $\mathrm{p}$-gvp genes encoding gas vesicles in Halobacterium salinarum. Microbiology 150, 1829-38 (2004).

22. Dennis, P. P. Ancient ciphers: translation in Archaea. Cell 89, 1007-10 (1997).

23. Benelli, D., Maone, E. \& Londei, P. Two different mechanisms for ribosome/mRNA interaction in archaeal translation initiation. Mol Microbiol 50, 635-43 (2003).

24. Sandman, K., Krzycki, J. A., Dobrinski, B., Lurz, R. \& Reeve, J. N. HMf, a DNA-binding protein isolated from the hyperthermophilic archaeon Methanothermus fervidus, is most closely related to histones. Proc Natl Acad Sci U S A 87, 5788-91 (1990).

This represents the first demonstration that (eury)archaea package their DNA using histones similar to eukaryotic homologues.

25. Reeve, J. N. Archaeal chromatin and transcription. Mol Microbiol 48, 587-98 (2003).

26. Bell, S. D., Botting, C. H., Wardleworth, B. N., Jackson, S. P. \& White, M. F. The interaction of Alba, a conserved archaeal chromatin protein, with Sir2 and its regulation by acetylation. Science 296, 148-51 (2002).

Histones are not found in crenarchaeota. This report describes a chromatin protein that is prevalent in crenarchaeota, and also found in a range of eukaryotic species. 
27. DiRuggiero, J., Brown, J. R., Bogert, A. P. \& Robb, F. T. DNA repair systems in Archaea: mementos from the last universal common ancestor? J Mol Evol 49, 474-84 (1999).

28. Bergerat, A. et al. An atypical topoisomerase II from Archaea with implications for meiotic recombination. Nature 386, 414-7 (1997).

A perfect illustration of how archaea can provide vital insights into eukaryotic biology. Homology to an archaeal topoisomerase helped identify Spo11 as the nuclease responsible for initiating meiotic recombination.

29. Seitz, E. M., Brockman, J. P., Sandler, S. J., Clark, A. J. \& Kowalczykowski, S. C. RadA protein is an archaeal RecA protein homolog that catalyzes DNA strand exchange. Genes Dev 12, 1248-53 (1998).

30. Woods, W. G. \& Dyall-Smith, M. L. Construction and analysis of a recombination-deficient (radA) mutant of Haloferax volcanii. Mol Microbiol 23, 791-7 (1997).

31. Komori, K. et al. Both RadA and RadB are involved in homologous recombination in Pyrococcus furiosus. $J$ Biol Chem 275, 33782-90 (2000).

32. Roberts, J. A., Bell, S. D. \& White, M. F. An archaeal XPF repair endonuclease dependent on a heterotrimeric PCNA. Mol Microbiol 48, 361-71 (2003).

33. McCready, S. \& Marcello, L. Repair of UV damage in Halobacterium salinarum. Biochem Soc Trans 31, 694-8 (2003).

34. Grogan, D. W. The question of DNA repair in hyperthermophilic archaea. Trends Microbiol 8, 180-5 (2000).

35. Makarova, K. S., Aravind, L., Grishin, N. V., Rogozin, I. B. \& Koonin, E. V. A DNA repair system specific for thermophilic Archaea and bacteria predicted by genomic context analysis. Nucleic Acids Res 30, 482-96 (2002).

36. Myllykallio, H. et al. Bacterial mode of replication with eukaryotic-like machinery in a hyperthermophilic archaeon. Science 288, 2212-5 (2000).

This study shows how archaea employ "eukaryotic" enzymes to replicate a circular chromosome in a highspeed "bacterial" fashion. As demonstrated in references 38 and 39, some archaea use more than one replication origin per chromosome.

37. Matsunaga, F., Forterre, P., Ishino, Y. \& Myllykallio, H. In vivo interactions of archaeal Cdc6/Orc1 and minichromosome maintenance proteins with the replication origin. Proc Natl Acad Sci U S A 98, 11152-7 (2001).

38. Robinson, N. P. et al. Identification of two origins of replication in the single chromosome of the archaeon Sulfolobus solfataricus. Cell 116, 25-38 (2004).

39. Lundgren, M., Andersson, A., Chen, L., Nilsson, P. \& Bernander, R. Three replication origins in Sulfolobus species: synchronous initiation of chromosome replication and asynchronous termination. Proc Natl Acad Sci U S A 101, 7046-51 (2004).

40. Galagan, J. E. et al. The genome of M. acetivorans reveals extensive metabolic and physiological diversity. Genome Res 12, 532-42 (2002).

41. Meuer, J., Kuettner, H. C., Zhang, J. K., Hedderich, R. \& Metcalf, W. W. Genetic analysis of the archaeon Methanosarcina barkeri Fusaro reveals a central role for Ech hydrogenase and ferredoxin in methanogenesis and carbon fixation. Proc Natl Acad Sci U S A 99, 5632-7 (2002).

42. Verhees, C. H. et al. The unique features of glycolytic pathways in Archaea. Biochem J 375, 231-46 (2003).

43. Makarova, K. S. \& Koonin, E. V. Filling a gap in the central metabolism of archaea: prediction of a novel aconitase by comparative-genomic analysis. FEMS Microbiol Lett 227, 17-23 (2003).

44. Siebers, B. et al. Reconstruction of the central carbohydrate metabolism of Thermoproteus tenax by use of genomic and biochemical data. J Bacteriol 186, 2179-94 (2004).

45. Cline, S. W. \& Doolittle, W. F. Efficient transfection of the archaebacterium Halobacterium halobium. J Bacteriol 169, 1341-4 (1987).

46. Charlebois, R. L., Lam, W. L., Cline, S. W. \& Doolittle, W. F. Characterization of pHV2 from Halobacterium volcanii and its use in demonstrating transformation of an archaebacterium. Proc Natl Acad Sci U S A 84, 8530-4 (1987).

Along with reference 45 , this is the first example of high-efficiency transformation of archaea. The authors went on to develop a series of shuttle vectors based on the pHV2 plasmid.

47. Tumbula, D. L., Makula, R. A. \& Whitman, W. B. Transformation of Methanococcus maripaludis and identification of a Pst I-like restriction system. FEMS Microbiol Lett 121, 309-314 (1994).

48. Lucas, S. et al. Construction of a shuttle vector for, and spheroplast transformation of, the hyperthermophilic archaeon Pyrococcus abyssi. Appl Environ Microbiol 68, 5528-36 (2002).

49. Patel, G. B., Nash, J. H. E., Agnew, B. J. \& Sprott, G. D. Natural and electroporation-mediated transformation of Methanococcus voltae protoplasts. Appl Environ Microbiol 60, 903-907 (1994).

50. Schleper, C., Kubo, K. \& Zillig, W. The particle SSV1 from the extremely thermophilic archaeon Sulfolobus is a virus: demonstration of infectivity and of transfection with viral DNA. Proc Natl Acad Sci U S A 89, 7645-9 (1992).

51. Cannio, R., Contursi, P., Rossi, M. \& Bartolucci, S. An autonomously replicating transforming vector for Sulfolobus solfataricus. J Bacteriol 180, 3237-40 (1998).

52. Metcalf, W. W., Zhang, J. K., Apolinario, E., Sowers, K. R. \& Wolfe, R. S. A genetic system for Archaea of the genus Methanosarcina: liposome-mediated transformation and construction of shuttle vectors. Proc Natl Acad Sci U S A 94, 2626-31 (1997).

This paper describes the development of critical tools that make possible genetic analysis in

Methanosarcina species. They have been adopted by researchers working on other methanogens.

53. Sato, T., Fukui, T., Atomi, H. \& Imanaka, T. Targeted gene disruption by homologous recombination in the hyperthermophilic archaeon Thermococcus kodakaraensis KOD1. J Bacteriol 185, 210-20 (2003).

54. Bertani, G. \& Baresi, L. Genetic transformation in the methanogen Methanococcus voltae PS. J Bacteriol 169, 27308 (1987). 
55. Meile, L., Abendschein, P. \& Leisinger, T. Transduction in the archaebacterium Methanobacterium thermoautotrophicum Marburg. J Bacteriol 172, 3507-8 (1990).

56. Bertani, G. Transduction-like gene transfer in the methanogen Methanococcus voltae. J Bacterio/ 181, 2992-3002 (1999).

57. Rosenshine, I., Tchelet, R. \& Mevarech, M. The mechanism of DNA transfer in the mating system of an archaebacterium. Science 245, 1387-9 (1989).

58. Mevarech, M. \& Werczberger, R. Genetic transfer in Halobacterium volcanii. J Bacteriol 162, 461-2 (1985).

59. Grogan, D. W. Exchange of genetic markers at extremely high temperatures in the archaeon Sulfolobus acidocaldarius. J Bacteriol 178, 3207-11 (1996).

60. Schleper, C., Holz, I., Janekovic, D., Murphy, J. \& Zillig, W. A multicopy plasmid of the extremely thermophilic archaeon Sulfolobus effects its transfer to recipients by mating. J Bacteriol 177, 4417-26 (1995).

61. Ghané, F. \& Grogan, D. W. Chromosomal marker exchange in the thermophilic archaeon Sulfolobus acidocaldarius: physiological and cellular aspects. Microbiology 144, 1649-1657 (1998).

62. Nolling, J. \& de Vos, W. M. Identification of the CTAG-recognizing restriction-modification systems MthZI and MthFI from Methanobacterium thermoformicicum and characterization of the plasmid-encoded mthZIM gene. Nucleic Acids Res 20, 5047-52 (1992).

63. Blaseio, U. \& Pfeifer, F. Transformation of Halobacterium halobium: development of vectors and investigation of gas vesicle synthesis. Proc Natl Acad Sci U S A 87, 6772-6 (1990).

64. Holmes, M. L., Nuttall, S. D. \& Dyall-Smith, M. L. Construction and use of halobacterial shuttle vectors and further studies on Haloferax DNA gyrase. J Bacteriol 173, 3807-13 (1991).

65. Grogan, D. W. Cytosine methylation by the SuaI restriction-modification system: implications for genetic fidelity in a hyperthermophilic archaeon. J Bacteriol 185, 4657-61 (2003).

66. Holmes, M. L. \& Dyall-Smith, M. L. A plasmid vector with a selectable marker for halophilic archaebacteria. J Bacteriol 172, 756-61 (1990).

67. Holmes, M. L. \& Dyall-Smith, M. L. Mutations in DNA gyrase result in novobiocin resistance in halophilic archaebacteria. J Bacteriol 173, 642-8 (1991).

68. Possot, O., Gernhardt, P., Klein, A. \& Sibold, L. Analysis of drug resistance in the archaebacterium Methanococcus voltae with respect to potential use in genetic engineering. Appl Environ Microbiol 54, 734-40 (1988).

69. Gernhardt, P., Possot, O., Foglino, M., Sibold, L. \& Klein, A. Construction of an integration vector for use in the archaebacterium Methanococcus voltae and expression of a eubacterial resistance gene. Mol Gen Genet 221, 2739 (1990).

70. Argyle, J. L., Tumbula, D. L. \& Leigh, J. A. Neomycin resistance as a selectable marker in Methanococcus maripaludis. Appl Environ Microbiol 62, 4233-7 (1996).

71. Boccazzi, P., Zhang, J. K. \& Metcalf, W. W. Generation of dominant selectable markers for resistance to pseudomonic acid by cloning and mutagenesis of the ileS gene from the archaeon Methanosarcina barkeri fusaro. $J$ Bacteriol 182, 2611-8 (2000).

72. Lam, W. L. \& Doolittle, W. F. Shuttle vectors for the archaebacterium Halobacterium volcanii. Proc Natl Acad Sci U $S$ A 86, 5478-82 (1989).

73. Wendoloski, D., Ferrer, C. \& Dyall-Smith, M. L. A new simvastatin (mevinolin)-resistance marker from Haloarcula hispanica and a new Haloferax volcanii strain cured of plasmid pHV2. Microbiology 147, 959-64. (2001).

74. Lange, M. \& Ahring, B. K. A comprehensive study into the molecular methodology and molecular biology of methanogenic Archaea. FEMS Microbiol Rev 25, 553-71 (2001).

75. Watrin, L., Martin-Jezequel, V. \& Prieur, D. Minimal amino acid requirements of the hyperthermophilic archaeon Pyrococcus abyssi, isolated from deep-sea hydrothermal vents. Appl Environ Microbiol 61, 1138-1140 (1995).

76. Haydock, A. K., Porat, I., Whitman, W. B. \& Leigh, J. A. Continuous culture of Methanococcus maripaludis under defined nutrient conditions. FEMS Microbiol Lett 238, 85-91 (2004).

77. Peck, R. F., Dassarma, S. \& Krebs, M. P. Homologous gene knockout in the archaeon Halobacterium salinarum with ura3 as a counterselectable marker. Mol Microbiol 35, 667-76 (2000).

The first use of a counter-selectable gene knock-out system in archaea. This technique has now been widely applied.

78. Wang, G., Kennedy, S. P., Fasiludeen, S., Rensing, C. \& DasSarma, S. Arsenic resistance in Halobacterium sp. strain NRC-1 examined by using an improved gene knockout system. J Bacteriol 186, 3187-94 (2004).

79. Bitan-Banin, G., Ortenberg, R. \& Mevarech, M. Development of a gene knockout system for the halophilic archaeon Haloferax volcanii by use of the pyrE gene. J Bacteriol 185, 772-8 (2003).

80. Allers, T., Ngo, H., Mevarech, M. \& Lloyd, R. G. Development of additional selectable markers for the halophilic archaeon Haloferax volcanii based on the leuB and trpA genes. Appl Environ Microbiol 70, 943-953 (2004).

81. Watrin, L., Lucas, S., Purcarea, C., Legrain, C. \& Prieur, D. Isolation and characterization of pyrimidine auxotrophs, and molecular cloning of the pyrE gene from the hyperthermophilic archaeon Pyrococcus abyssi. Mol Gen Genet 262, 378-81 (1999).

82. Grogan, D. W. Selectable mutant phenotypes of the extremely thermophilic archaebacterium Sulfolobus acidocaldarius. J Bacteriol 173, 7725-7 (1991).

83. Jonuscheit, M., Martusewitsch, E., Stedman, K. M. \& Schleper, C. A reporter gene system for the hyperthermophilic archaeon Sulfolobus solfataricus based on a selectable and integrative shuttle vector. Mol Microbiol 48, $1241-52$ (2003).

This report describes a sophisticated genetic system for Sulfolobus solfataricus. Genetic studies of hyperthermophiles are relatively rare, but the tools described here should facilitate future investigations. 
84. Martusewitsch, E., Sensen, C. W. \& Schleper, C. High spontaneous mutation rate in the hyperthermophilic archaeon Sulfolobus solfataricus is mediated by transposable elements. J Bacteriol 182, 2574-81 (2000).

85. Sapienza, C., Rose, M. R. \& Doolittle, W. F. High-frequency genomic rearrangements involving archaebacterial repeat sequence elements. Nature 299, 182-5 (1982).

86. Worthington, P., Hoang, V., Perez-Pomares, F. \& Blum, P. Targeted disruption of the alpha-amylase gene in the hyperthermophilic archaeon Sulfolobus solfataricus. J Bacteriol 185, 482-8 (2003).

87. Bowen, T. L. \& Whitman, W. B. Incorporation of exogenous purines and pyrimidines by Methanococcus voltae and isolation of analog-resistant mutants. Appl Environ Microbiol 53, 1822-1826 (1987).

88. Pritchett, M. A., Zhang, J. K. \& Metcalf, W. W. Development of a markerless genetic exchange method for Methanosarcina acetivorans $\mathrm{C} 2 \mathrm{~A}$ and its use in construction of new genetic tools for methanogenic archaea. Appl Environ Microbiol 70, 1425-33 (2004).

89. Moore, B. C. \& Leigh, J. A. Markerless mutagenesis in Methanococcus maripaludis demonstrates roles for alanine dehydrogenase, alanine racemase, and alanine permease. $J$ Bacteriol (In press).

90. Ladapo, J. \& Whitman, W. B. Method for isolation of auxotrophs in the methanogenic archaebacteria: role of the acetyl-CoA pathway of autotrophic CO2 fixation in Methanococcus maripaludis. Proc Natl Acad Sci U S A 87, 5598$602(1990)$.

91. Watrin, L. \& Prieur, D. UV and ethyl methanesulfonate effects in hyperthermophilic archaea and isolation of auxotrophic mutants of Pyrococcus strains. Curr Microbiol 33, 377-82 (1996).

92. Blank, C. E., Kessler, P. S. \& Leigh, J. A. Genetics in methanogens: transposon insertion mutagenesis of a Methanococcus maripaludis nifH gene. J Bacteriol 177, 5773-7 (1995).

93. Zhang, J. K., Pritchett, M. A., Lampe, D. J., Robertson, H. M. \& Metcalf, W. W. In vivo transposon mutagenesis of the methanogenic archaeon Methanosarcina acetivorans $\mathrm{C} 2 \mathrm{~A}$ using a modified version of the insect mariner-family transposable element Himar1. Proc Natl Acad Sci U S A 97, 9665-70 (2000).

94. Dyall-Smith, M. L. \& Doolittle, W. F. Construction of composite transposons for halophilic Archaea. Can J Microbiol 40, 922-9 (1994).

95. Jarrell, K. F., Bayley, D. P., Florian, V. \& Klein, A. Isolation and characterization of insertional mutations in flagellin genes in the archaeon Methanococcus voltae. Mol Microbiol 20, 657-66 (1996).

96. Thomas, N. A., Mueller, S., Klein, A. \& Jarrell, K. F. Mutants in flaI and flaJ of the archaeon Methanococcus voltae are deficient in flagellum assembly. Mol Microbiol 46, 879-87 (2002).

97. Berghöfer, Y. \& Klein, A. Insertional mutations in the hydrogenase vhc and frc operons encoding selenium-free hydrogenases in Methanococcus voltae. Appl Environ Microbiol 61, 1770-1775 (1995).

98. Kim, W. \& Whitman, W. B. Isolation of acetate auxotrophs of the methane-producing archaeon Methanococcus maripaludis by random insertional mutagenesis. Genetics 152, 1429-37 (1999).

99. Stedman, K. M., Schleper, C., Rumpf, E. \& Zillig, W. Genetic requirements for the function of the archaeal virus SSV1 in Sulfolobus solfataricus. Construction and testing of viral shuttle vectors. Genetics 152, 1397-405 (1999).

100. Elferink, M. G., Schleper, C. \& Zillig, W. Transformation of the extremely thermoacidophilic archaeon Sulfolobus solfataricus via a self-spreading vector. FEMS Microbiol Lett 137, 31-5 (1996).

101. Krebs, M. P., Hauss, T., Heyn, M. P., RajBhandary, U. L. \& Khorana, H. G. Expression of the bacterioopsin gene in Halobacterium halobium using a multicopy plasmid. Proc Natl Acad Sci U S A 88, 859-63 (1991).

102. Tumbula, D. L., Bowen, T. L. \& Whitman, W. B. Characterization of pURB500 from the archaeon Methanococcus maripaludis and construction of a shuttle vector. J Bacteriol 179, 2976-86 (1997).

103. Gardner, W. L. \& Whitman, W. B. Expression vectors for Methanococcus maripaludis: overexpression of acetohydroxyacid synthase and beta-galactosidase. Genetics 152, 1439-47 (1999).

104. Erauso, G. et al. Sequence of plasmid pGT5 from the archaeon Pyrococcus abyssi: evidence for rolling-circle replication in a hyperthermophile. J Bacteriol 178, 3232-7 (1996).

105. Aagaard, C. et al. General vectors for archaeal hyperthermophiles: strategies based on a mobile intron and a plasmid. FEMS Microbiol Rev 18, 93-104 (1996).

106. Aravalli, R. N. \& Garrett, R. A. Shuttle vectors for hyperthermophilic archaea. Extremophiles 1, 183-91 (1997).

107. Beneke, S., Bestgen, H. \& Klein, A. Use of the Escherichia coli uidA gene as a reporter in Methanococcus voltae for the analysis of the regulatory function of the intergenic region between the operons encoding selenium-free hydrogenases. Mol Gen Genet 248, 225-8 (1995).

108. Holmes, M. L. \& Dyall-Smith, M. L. Sequence and expression of a halobacterial beta-galactosidase gene. Mol Microbiol 36, 114-122 (2000).

109. Patenge, N., Haase, A., Bolhuis, H. \& Oesterhelt, D. The gene for a halophilic beta-galactosidase (bgaH) of Haloferax alicantei as a reporter gene for promoter analyses in Halobacterium salinarum. Mol Microbiol 36, 105-113 (2000).

110. Gregor, D. \& Pfeifer, F. Use of a halobacterial $b g a \mathrm{H}$ reporter gene to analyse the regulation of gene expression in halophilic archaea. Microbiology 147, 1745-54. (2001).

111. Pisani, F. M. et al. Thermostable beta-galactosidase from the archaebacterium Sulfolobus solfataricus. Purification and properties. Eur J Biochem 187, 321-8 (1990).

112. Grogan, D. W. Evidence that beta-galactosidase of Sulfolobus solfataricus is only one of several activities of a thermostable beta-D-glycosidase. Appl Environ Microbiol 57, 1644-1649 (1991).

113. Schleper, C., Roder, R., Singer, T. \& Zillig, W. An insertion element of the extremely thermophilic archaeon Sulfolobus solfataricus transposes into the endogenous beta-galactosidase gene. Mol Gen Genet 243, 91-6 (1994).

114. Sniezko, I., Dobson-Stone, C. \& Klein, A. The treA gene of Bacillus subtilis is a suitable reporter gene for the archaeon Methanococcus voltae. FEMS Microbiol Lett 164, 237-42 (1998). 
115. Reuter, C. J. \& Maupin-Furlow, J. Analysis of proteasome-dependent proteolysis in Haloferax volcanii cells using short-lived green fluorescent proteins. Appl Environ Microbiol (In press).

116. Baliga, N. S. et al. Systems level insights into the stress response to UV radiation in the halophilic archaeon Halobacterium NRC-1. Genome Res (2004).

117. Zaigler, A., Schuster, S. C. \& Soppa, J. Construction and usage of a onefold coverage shotgun DNA microarray to characterize the metabolism of the archaeon Haloferax volcanii. Mol Microbiol 48, 1089-1105 (2003).

118. Hjort, K. \& Bernander, R. Cell cycle regulation in the hyperthermophilic crenarchaeon Sulfolobus acidocaldarius. Mol Microbiol 40, 225-34 (2001).

119. Sowers, K. R. \& Schreier, H. J. Gene transfer systems for the Archaea. Trends Microbiol 7, 212-9 (1999).

120. Metcalf, W. W. in Genetic Methods for Diverse Prokaryotes (eds. Smith, M. C. M. \& Sockett, R. E.) 277-326 (Academic Press, London, 1999).

121. Kuo, Y. P., Thompson, D. K., St Jean, A., Charlebois, R. L. \& Daniels, C. J. Characterization of two heat shock genes from Haloferax volcanii: a model system for transcription regulation in the Archaea. J Bacteriol 179, 6318-24. (1997).

122. Howland, J. L. The surprising archaea: discovering another domain of life (Oxford University Press Inc, USA, 2000).

123. Sowers, K. R. \& Schreier, H. J. (eds.) Archaea: A Laboratory Manual (Cold Spring Harbor Laboratory Press, Cold Spring Harbor, New York, 1995).

124. Robb, F. T. \& Place, A. R. (eds.) Archaea: A Laboratory Manual (Cold Spring Harbor Laboratory Press, Cold Spring Harbor, New York, 1995).

125. DasSarma, S. \& Fleischmann, E. M. (eds.) Archaea: A Laboratory Manual (Cold Spring Harbor Laboratory Press, Cold Spring Harbor, New York, 1995).

126. Crick, F. H. C. On protein synthesis. Symp Soc Exp Biol 12, 138-163 (1958).

127. Fox, G. E., Magrum, L. J., Balch, W. E., Wolfe, R. S. \& Woese, C. R. Classification of methanogenic bacteria by $16 \mathrm{~S}$ ribosomal RNA characterization. Proc Natl Acad Sci U S A 74, 4537-4541 (1977).

128. Huber, H. et al. A new phylum of Archaea represented by a nanosized hyperthermophilic symbiont. Nature 417, 63-7 (2002).

This paper describes Nanoarchaeum equitans, an obligate symbiont that grows in coculture with the crenarchaeon Ignicoccus. The $\boldsymbol{N}$. equitans genome, which is only $491 \mathrm{~kb}$ in size, encodes the machinery for information processing but lacks the genes for amino acid, lipid and nucleotide biosynthesis.

129. Barns, S. M., Delwiche, C. F., Palmer, J. D. \& Pace, N. R. Perspectives on archaeal diversity, thermophily and monophyly from environmental rRNA sequences. Proc Natl Acad Sci U S A 93, 9188-93 (1996).

130. Koonin, E. V., Makarova, K. S. \& Aravind, L. Horizontal gene transfer in prokaryotes: quantification and classification. Annu Rev Microbiol 55, 709-42 (2001).

131. Doolittle, W. F. et al. How big is the iceberg of which organellar genes in nuclear genomes are but the tip? Philos Trans $R$ Soc Lond B Biol Sci 358, 39-57; discussion 57-8 (2003).

132. Kennedy, S. P., Ng, W. V., Salzberg, S. L., Hood, L. \& DasSarma, S. Understanding the adaptation of Halobacterium species NRC-1 to its extreme environment through computational analysis of its genome sequence. Genome Res 11, 1641-50 (2001).

133. Deppenmeier, U. et al. The genome of Methanosarcina mazei: evidence for lateral gene transfer between bacteria and archaea. J Mol Microbiol Biotechnol 4, 453-61 (2002).

134. Brown, J. R. \& Doolittle, W. F. Archaea and the prokaryote-to-eukaryote transition. Microbiol Mol Biol Rev 61, $456-$ $502(1997)$.

135. Boucher, Y., Douady, C. J., Sharma, A. K., Kamekura, M. \& Doolittle, W. F. Intragenomic heterogeneity and intergenomic recombination among haloarchaeal rRNA genes. J Bacteriol 186, 3980-90 (2004).

136. Deppenmeier, U. The unique biochemistry of methanogenesis. Prog Nucleic Acid Res Mol Biol 71, $223-83$ (2002).

137. Forterre, P. A hot story from comparative genomics: reverse gyrase is the only hyperthermophile-specific protein. Trends Genet 18, 236-7 (2002).

138. Venter, J. C. et al. Environmental genome shotgun sequencing of the Sargasso Sea. Science 304, 66-74 (2004).

The high-throughput techniques used in this study provide a snapshot of microbial biodiversity, without

the bias inherent in traditional culture methods. In conjunction with other environmental studies, it

suggests that archaea are extant in most any habitat examined.

139. Eckburg, P. B., Lepp, P. W. \& Relman, D. A. Archaea and their potential role in human disease. Infect Immun 71, 591-6 (2003).

140. Lepp, P. W. et al. Methanogenic Archaea and human periodontal disease. Proc Natl Acad Sci U S A 101, 6176-81 (2004)

141. Gophna, U., Charlebois, R. L. \& Doolittle, W. F. Have archaeal genes contributed to bacterial virulence? Trends Microbiol 12, 213-9 (2004).

142. Sprott, G. D., Dicaire, C. J., Gurnani, K., Deschatelets, L. A. \& Krishnan, L. Liposome adjuvants prepared from the total polar lipids of Haloferax volcanii, Planococcus spp. and Bacillus firmus differ in ability to elicit and sustain immune responses. Vaccine 22, 2154-62 (2004).

143. Hungate, R. E. in Methods in Microbiology (eds. Noriss, J. R. \& Ribbons, D. W.) 117-132 (Academic Press, New York, 1969).

144. Balch, W. E., Fox, G. E., Magrum, L. J., Woese, C. R. \& Wolfe, R. S. Methanogens: reevaluation of a unique biological group. Microbiol Rev 43, 260-96 (1979).

145. Cline, S. W. \& Doolittle, W. F. Transformation of members of the genus Haloarcula with shuttle vectors based on Halobacterium halobium and Haloferax volcanii plasmid replicons. J. Bacteriol. 174, 1076-1080 (1992). 
146. Cline, S. W., Lam, W. L., Charlebois, R. L., Schalkwyk, L. C. \& Doolittle, W. F. Transformation methods for halophilic archaebacteria. Can J Microbiol 35, 148-52 (1989).

147. Contursi, P. et al. Development of a genetic system for hyperthermophilic Archaea: expression of a moderate thermophilic bacterial alcohol dehydrogenase gene in Sulfolobus solfataricus. FEMS Microbiol Lett 218, 115-20 (2003).

148. Mankin, A. S., Zyrianova, I. M., Kagramanova, V. K. \& Garrett, R. A. Introducing mutations into the single-copy chromosomal 23S rRNA gene of the archaeon Halobacterium halobium by using an rRNA operon-based transformation system. Proc Natl Acad Sci U S A 89, 6535-9 (1992).

149. Nuttall, S. D., Deutschel, S. E., Irving, R. A., Serrano-Gomicia, J. A. \& Dyall-Smith, M. L. The ShBle resistance determinant from Streptoalloteichus hindustanus is expressed in Haloferax volcanii and confers resistance to bleomycin. Biochem J 346 Pt 2, 251-4 (2000).

150. Cannio, R., Contursi, P., Rossi, M. \& Bartolucci, S. Thermoadaptation of a mesophilic hygromycin B phosphotransferase by directed evolution in hyperthermophilic Archaea: selection of a stable genetic marker for DNA transfer into Sulfolobus solfataricus. Extremophiles 5, 153-9 (2001).

151. Jenal, U. et al. Isoleucyl-tRNA synthetase of Methanobacterium thermoautotrophicum Marburg. Cloning of the gene, nucleotide sequence, and localization of a base change conferring resistance to pseudomonic acid. $\mathrm{J}$ Biol Chem 266, 10570-7 (1991).

152. Sandbeck, K. A. \& Leigh, J. A. Recovery of an integration shuttle vector from tandem repeats in Methanococcus maripaludis. Appl Environ Microbiol 57, 2762-3 (1991).

153. de Macario, E. C., Guerrini, M., Dugan, C. B. \& Macario, A. J. Integration of foreign DNA in an intergenic region of the archaeon Methanosarcina mazei without effect on transcription of adjacent genes. J Mol Biol 262, 12-20 (1996).

154. Ortenberg, R., Rozenblatt-Rosen, O. \& Mevarech, M. The extremely halophilic archaeon Haloferax volcanii has two very different dihydrofolate reductases. Mol Microbiol 35, 1493-1505 (2000).

155. Pfeiffer, M., Bestgen, H., Burger, A. \& Klein, A. The vhuU gene encoding a small subunit of a selenium-containing [NiFe]-hydrogenase in Methanococcus voltae appears to be essential for the cell. Arch Microbiol 170, 418-26 (1998).

156. Conover, R. K. \& Doolittle, W. F. Characterization of a gene involved in histidine biosynthesis in Halobacterium (Haloferax) volcanii: isolation and rapid mapping by transformation of an auxotroph with cosmid DNA. J Bacteriol 172, 3244-9 (1990).

157. Danner, S. \& Soppa, J. Characterization of the distal promoter element of halobacteria in vivo using saturation mutagenesis and selection. Mol Microbiol 19, 1265-76 (1996). 


\section{Online Resources}

\begin{tabular}{|c|c|c|c|c|c|c|}
\hline Vector & Host & $\begin{array}{l}\text { Archaeal } \\
\text { replicon }\end{array}$ & $\begin{array}{l}\text { Archaeal } \\
\text { marker(s) }\end{array}$ & $\begin{array}{l}\text { Size } \\
(\mathbf{k b p})\end{array}$ & References & Notes \\
\hline $\begin{array}{l}\text { pWL102, } \\
\text { pWL104 }\end{array}$ & $\begin{array}{l}\text { Har } \\
\text { Hbt } \\
\text { Hvo }\end{array}$ & pHV2 & $\operatorname{Mev}^{R}$ & $10.5,8.7$ & $1-4$ & $\begin{array}{l}\text { pHV2 plasmid from Haloferax volcanii. Laboratory strains WFD11 and } \\
\text { DS70 are cured of pHV2, enabling use of this replicon for shuttle vectors. }\end{array}$ \\
\hline pWL204 & Hvo & pHV2 & $\mathrm{Mev}^{\mathrm{R}}$ & 10.4 & 5 & Expression vector based on pWL102 with tRNA ${ }^{\text {Lys }}$ promoter. \\
\hline pMDS99 & Hvo & pHV2 & $\mathrm{Mev}^{\mathrm{R}}$ & 7.3 & 6 & $\mathrm{Mev}^{\mathrm{R}}$ marker from Haloarcula hispanica. \\
\hline pUBP2 & $\begin{array}{l}\text { Har } \\
\text { Hbt } \\
\text { Hvo }\end{array}$ & $\begin{array}{l}\text { pHH9 } \\
\text { (pHH1) }\end{array}$ & $\operatorname{Mev}^{\mathrm{R}}$ & 12.3 & 2,3 & $\mathrm{pHH} 9$ is a deletion derivative of $\mathrm{pHH} 1$. \\
\hline pNG168 & $\mathrm{Hbt}$ & pNRC100 & $\mathrm{Mev}^{\mathrm{R}}$ & 8.9 & 4 & Polylinker in lacZ' for blue/white screening in Escherichia coli. \\
\hline pMPK54, 56 & $\mathrm{Hbt}$ & pGRB1 & $\mathrm{Mev}^{\mathrm{R}}$ & $8.6,5.4$ & 7,8 & $\begin{array}{l}\text { pMPK } 56 \text { is more stable than pMPK } 54 \text {, but does not have an E. coli replicon } \\
\text { or marker. }\end{array}$ \\
\hline pNOB102 & $\begin{array}{l}\mathrm{Har} \\
\mathrm{Hbt}\end{array}$ & pNOB1 & $\operatorname{Mev}^{R}$ & 9.1 & 9,10 & pNOB1 from Natronobacterium sp. strain AS7091, see also pNOB103. \\
\hline pMLH3 & Hvo & pHK2 & $\mathrm{Mev}^{\mathrm{R}} \& \mathrm{Nov}^{\mathrm{R}}$ & 11.3 & 11 & Dual-marker plasmid. \\
\hline pMDS20 & Hvo & pHK2 & $\operatorname{Nov}^{R}$ & 10 & $11-13$ & Derived from pMDS10, see also pMDS1, 2, 8, 9, and 11. \\
\hline pWL-Nov & Hvo & pHV2 & $\operatorname{Nov}^{\mathrm{R}}$ & 9.4 & 14 & Derived from $\mathrm{pWL} 102$ \\
\hline pBR-Nov, pUC- & Hvo & - & Nov $^{R}$ & $5.7,5.1$ & 14 & \\
\hline $\begin{array}{l}\text { Nov } \\
\text { pHRZ }\end{array}$ & $\mathrm{Hbt}$ & ND & $\mathrm{Ani}^{\mathrm{R}} \mathrm{Ths}^{\mathrm{R}}$ & 12.6 & 15 & \\
\hline $\mathrm{pHRZH}$ & $\mathrm{Hbt}$ & - & Ani $^{\mathrm{R}} \mathrm{Ths}^{\mathrm{R}}$ & 14.4 & 15 & Derived from $\mathrm{pHRZ}$. \\
\hline pMPK408 & $\mathrm{Hbt}$ & - & ura3 & 4.1 & 16,17 & Vector for gene knockout with 5-FOA, requires Halobacterium $\Delta$ ura 3 host. \\
\hline pGB70 & Hvo & - & pyrE2 & 3.3 & 18 & Vector for gene knockout with 5-FOA, requires $H f x$. volcanii $\Delta p y r E 2$ host. \\
\hline $\begin{array}{l}\text { pTA } 131,132, \\
133,192\end{array}$ & Hvo & - & $\begin{array}{l}\text { pyrE } 2 \operatorname{trp} A \\
\text { leuB } B, h d r B\end{array}$ & $\begin{array}{l}3.6,3.9 \\
4.1,3.7\end{array}$ & 19 & $\begin{array}{l}\text { pTA131 vector for gene knockout with 5-FOA. Require } H f x \text {. volcanii } \\
\Delta p y r E 2, \Delta \operatorname{trp} A, \Delta l e u B \text { or } \Delta h d r B \text { hosts respectively. Polylinker in lacZ' for } \\
\text { blue/white screening in } E \text {. coli. }\end{array}$ \\
\hline $\begin{array}{l}\text { pTA230, 231, } \\
232,233\end{array}$ & Hvo & pHV2 & $\begin{array}{l}\text { pyrE } 2 \operatorname{trp} A \\
\text { leuB, } h d r B\end{array}$ & $\begin{array}{l}7.4,7.7 \\
7.8,7.4\end{array}$ & 19 & $\begin{array}{l}\text { Shuttle vectors derived from pTA131, 132, 133, 192, similar host } \\
\text { requirement. }\end{array}$ \\
\hline pMIP1 & Mvo & - & $\operatorname{Pur}^{\mathrm{R}}$ & 7.4 & 20 & $\begin{array}{l}\text { Also contains his } A \text { sequences for integration into Methanococcus voltae } \\
\text { genome. }\end{array}$ \\
\hline pMEB. 2 & Mma & - & Pur $^{R}$ & 5.0 & 20,21 & pUC18 with pac cassette for Pur ${ }^{\mathrm{R}}$. \\
\hline pKAS102 & Mma & - & $\operatorname{Pur}^{R}$ & 12.1 & 22 & $\begin{array}{l}\text { Derived from pMIP1, with } 4.7 \mathrm{~kb} \text { insert of Methanococcus maripaludis } \\
\text { argH gene, for integration into genome. }\end{array}$ \\
\hline pWAY1, 2 & $\mathrm{Mmz}$ & - & $\operatorname{Pur}^{R}$ & 5.5 & 23 & \\
\hline
\end{tabular}




\begin{tabular}{|c|c|c|c|c|c|c|}
\hline pUC::pac & Mvo & - & Pur $^{\mathrm{R}}$ & 5.0 & 24,25 & pUC BM21 with pac cassette for Pur ${ }^{\mathrm{R}}$. \\
\hline pJK29, 41 & $\begin{array}{l}\text { Mac } \\
\text { Mba }\end{array}$ & - & Pur $^{R}$ & $3.2,3.5$ & 26 & $\begin{array}{l}\text { Polylinker in lacZ' for blue/white screening in E. coli. Require E. coli pir } \\
\text { host for replication using oriR6K origin. See also pJK31,33, 35, 37, and } \\
39 \text {. }\end{array}$ \\
\hline pWLG13, 18 & Mma & - & Pur $^{\mathrm{R}}$ & $4.4,7.5$ & 27 & $\begin{array}{l}\text { Contains } \mathrm{P}_{h m v A} \text { promoter for gene expression in } M . \text { maripaludis. pWL18 } \\
\text { contains polylinker in lacZ' for blue/white screening in } E \text {. coli. See also } \\
\text { pWLG11.12A. } 14\end{array}$ \\
\hline $\begin{array}{l}\text { pWM307, } 311, \\
321\end{array}$ & $\begin{array}{l}\text { Mac } \\
\text { Mba }\end{array}$ & $\mathrm{pC} 2 \mathrm{~A}$ & Pur $^{R}$ & $\begin{array}{l}8.2,8.7, \\
8.9\end{array}$ & 28,29 & $\begin{array}{l}\text { pWM311 contains polylinker in } l a c Z^{\prime} \text { for blue/white screening in } E \text {. coli. } \\
\text { See also pWM } 309,313,315 \text {, and } 317,319 \text {. }\end{array}$ \\
\hline pDLT44 & Mma & pURB500 & Pur $^{\mathrm{R}}$ & 12.7 & 30 & Not very stable in E. coli. \\
\hline pWLG30 & Mma & pURB500 & Pur $^{R}$ & 12.7 & & $\begin{array}{l}\text { Derived from pWLG14. Contains } \mathrm{P}_{h m v A} \text { promoter for gene expression in } M \text {. } \\
\text { maripaludis. See also pWL30+lacZ (contains lacZ' for blue/white screening } \\
\text { in E. coli) }\end{array}$ \\
\hline pRCZ113 & Mma & - & Pur $^{\mathrm{R}}$ & 16 & 31 & $\begin{array}{l}\text { Transcriptional reporter construct using lac } Z \text {, includes } M \text {. maripaludis argH } \\
\text { gene for integration into genome. }\end{array}$ \\
\hline Miptre & Mvo & - & Pur $^{R}$ & 8.7 & 32 & $\begin{array}{l}\text { Transcriptional reporter construct using tre } A \text {, includes } M \text {. voltae his } A \text { gene } \\
\text { for integration into genome. }\end{array}$ \\
\hline pMudpur & Mma & - & Pur $^{R}$ & 7.3 & 33 & Contains Mud transposon for insertional mutagenesis. \\
\hline pWM381 & Mac & - & Pur $^{\mathrm{R}}$ & 7.5 & 34 & $\begin{array}{l}\text { Mini-mariner delivery plasmid for in vivo transposon mutagenesis in } \\
\text { Methanosarcina acetivorans. See also pWM } 379,383,385 \text {. }\end{array}$ \\
\hline pPAC60 & Mvo & - & Pur $^{R}$ & 4.7 & 35 & $\begin{array}{l}\text { Vector for insertional mutagenesis, includes } h m v A \text { promoter to drive } \\
\text { transcription of genes downstream of insertion. }\end{array}$ \\
\hline pMP44 & Mac & - & hpt Pur $^{\mathrm{R}}$ & 4.2 & 36 & $\begin{array}{l}\text { Counter-selectable plasmid for marker-less gene deletion in } M . \text { acetivorans. } \\
\text { Requires E. coli pir host for replication using oriR6K origin. }\end{array}$ \\
\hline pCRPrtNeo & Mma & - & hpt $\mathrm{Neo}^{\mathrm{R}}$ & 6.5 & 37 & $\begin{array}{l}\text { Counter-selectable plasmid for marker-less gene deletion in } M \text {. } \\
\text { maripaludis. }\end{array}$ \\
\hline pJLA5, 6 & Mma & - & $\mathrm{Neo}^{\mathrm{R}}$ & $5.6,5.8$ & 38 & \\
\hline pHisuid & Mvo & - & hisA & 6.6 & 39 & $\begin{array}{l}\text { Integration of plasmid reconstitutes his } A \text { gene, requires } M \text {. voltae his } A \text { host. } \\
\text { Also contains } h m v A \text { promoter linked to uidA glucuronidase gene of } E \text {. coli. } \\
\text { See also pHisuid- } v h c \text { and -frc. }\end{array}$ \\
\hline pPB31-35 & Mac & $\mathrm{pC} 2 \mathrm{~A}$ & $\mathrm{PA}^{\mathrm{R}}$ & 11.3 & 29,40 & $\begin{array}{l}\text { Polylinker in lacZ' for blue/white screening in } E \text {. coli. Require } E \text {. coli pir } \\
\text { host for replication using oriR6K origin. }\end{array}$ \\
\hline pJK89 & Mac & $\mathrm{pC} 2 \mathrm{~A}$ & proC & 9.1 & 36 & Requires $M$. acetivorans $\triangle$ pro $C$ host. \\
\hline pKMSD48 & Sso & SSV1 & - & 18.5 & 41 & $\begin{array}{l}\text { Derived from SSV1 virus with insertion of pBluescript II SK+. No } \\
\text { selectable marker, transformants form viral plaques on lawn of sensitive } \\
\text { cells. }\end{array}$ \\
\hline pEXSs & Sso & SSV1 & $h p h$ & 6.4 & 42 & $\begin{array}{l}\text { Replicon based on SSV1 viral autonomously replicating sequence, copy } \\
\text { number in Sulfolobus solfataricus increased by exposure of cells to }\end{array}$ \\
\hline
\end{tabular}




\begin{tabular}{|c|c|c|c|c|c|c|}
\hline $\mathrm{nFXADH}$ & Sso & SSV1 & hnh adh_hT & 77 & 43 & mitomycin C or UV. Not widely used. \\
\hline $\mathrm{pEXlacOP}$ & Sso & SSV1 & $\begin{array}{l}\text { hph } \\
\text { lacS-lacTr }\end{array}$ & 11.7 & 44 & $\begin{array}{l}\text { Derived from pEXSs. Contains lacTr-lacS operon, requires } S \text {. solfataricus } \\
\text { G } \theta \mathrm{W} \Delta \mathrm{lac} S \text { - } \Delta \text { lacTr host. }\end{array}$ \\
\hline pSSV64 & Sso & SSV1 & pyrEF & 20.1 & 45 & Derived from pKMSD48, requires $S$. solfataricus pyrE or $p y r F$ mutant host \\
\hline pJM03 & Sso & SSV1 & pyrEF lacS & 21.8 & 45 & Derived from pSSV64, requires $S$. solfataricus lacS pyrE/F host. \\
\hline pNOB8::lacS & Sso & pNOB8 & lacS & 43 & 46 & $\begin{array}{l}\text { pNOB } 8 \text { is self-spreading conjugative plasmid, selectable marker not } \\
\text { necessary, lac } S \text { used as phenotypic marker. pNOB } 8 \text { imposes severe growth } \\
\text { defect on host strain. }\end{array}$ \\
\hline pRN1-pUC18 & Sso & pRN1 & - & 8.0 & 47 & Used to develop transformation protocols for S. solfataricus. \\
\hline pRN1::lacS & Sso & pRN1 & lac $S$ & 7.1 & 48 & lacS used as a phenotypic marker. pRN1-based plasmids not widely used. \\
\hline pDMI1 & $\mathrm{Sac}$ & $\begin{array}{l}23 \mathrm{~S} \text { rRNA } \\
\text { intron }\end{array}$ & - & 3.7 & 49 & $\begin{array}{l}\text { Replicon uses self-spreading mobile intron from 23SrRNA gene of } \\
\text { Desulfurococcus mobilis. Selectable marker not necessary. }\end{array}$ \\
\hline pCSV1 & Pfu Sac & pGT5 & - & 6.1 & 49 & $\begin{array}{l}\text { pGT5 plasmid from Pyrococcus furiosus, replicates in both euryarchaeota } \\
\text { and crenarchaeota. }\end{array}$ \\
\hline pAG21 & Pfu Sac & pGT5 & $a d h$ & 6.5 & 50 & $\begin{array}{l}\text { See also pAG1 and 2, less stable in E. coli than pAG21 due to high copy } \\
\text { number. }\end{array}$ \\
\hline pYS2 & $\mathrm{Pab}$ & pGT5 & pyrE & 6.4 & 51 & $\begin{array}{l}\text { pyrE marker from Sulfolobus acidocaldarius. Requires pyrE mutant of } \\
\text { Pyrococcus abyssi GE9 strain (devoid of pGT5). }\end{array}$ \\
\hline pUDT2 & Tko & - & pyrF & 6.0 & 52 & $\begin{array}{l}\text { Plasmid for deletion of } \operatorname{trp} E \text { gene from genome by double crossover. Used } \\
\text { to develop gene knockout system for Thermococcus kodakaraensis. }\end{array}$ \\
\hline
\end{tabular}

\section{Commonly used plasmid vectors for archaeal genetics}

Host species abbreviations, see Table 1. Replicon not determined (ND); integrative vector (-). Markers, see Table 2.

\section{References}

1. Lam, W. L. \& Doolittle, W. F. Shuttle vectors for the archaebacterium Halobacterium volcanii. Proc Natl Acad Sci U S A 86, 5478-82 (1989).

2. Blaseio, U. \& Pfeifer, F. Transformation of Halobacterium halobium: development of vectors and investigation of gas vesicle synthesis. Proc Natl Acad Sci U $S$ A 87, $6772-6$ (1990).

3. Cline, S. W. \& Doolittle, W. F. Transformation of members of the genus Haloarcula with shuttle vectors based on Halobacterium halobium and Haloferax volcanii plasmid replicons. J. Bacteriol. 174, 1076-1080 (1992).

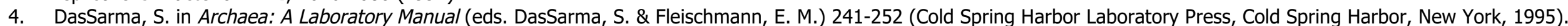

5. Nieuwlandt, D. T. \& Daniels, C. J. An expression vector for the archaebacterium Haloferax volcanii. J. Bacteriol. 172, 7104-7110 (1990).

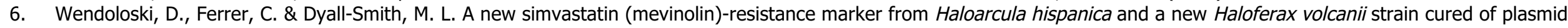
pHV2. Microbiology 147, 959-64. (2001).

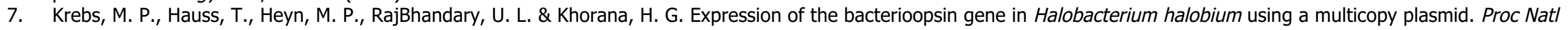
Acad Sci U S A 88, 859-63 (1991).

8. Krebs, M. P., Mollaaghababa, R. \& Khorana, H. G. Gene replacement in Halobacterium halobium and expression of bacteriorhodopsin mutants. Proc Natl Acad Sci U S A 90, 1987-91 (1993). 


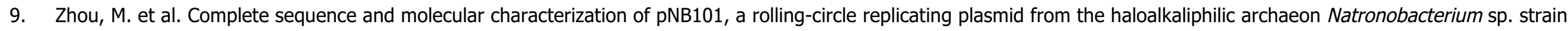
AS7091. Extremophiles 8, 91-8 (2004).

10. Zhou, M., Xiang, H., Sun, C. \& Tan, H. Construction of a novel shuttle vector based on an RCR-plasmid from a haloalkaliphilic archaeon and transformation into other haloarchaea. Biotechnol Lett 26, 1107-13 (2004).

11. Holmes, M., Pfeifer, F. \& Dyall-Smith, M. Improved shuttle vectors for Haloferax volcanii including a dual-resistance plasmid. Gene 146, 117-21 (1994).

12. Holmes, M. L., Nuttall, S. D. \& Dyall-Smith, M. L. Construction and use of halobacterial shuttle vectors and further studies on Haloferax DNA gyrase. J Bacterio/ 173, 3807-13 (1991).

13. Holmes, M. L. \& Dyall-Smith, M. L. Mutations in DNA gyrase result in novobiocin resistance in halophilic archaebacteria. $J$ Bacterio/ 173, 642-8 (1991).

14. Ortenberg, R., Rozenblatt-Rosen, O. \& Mevarech, M. The extremely halophilic archaeon Haloferax volcanii has two very different dihydrofolate reductases. Mol Microbio/ 35, 1493-1505 (2000).

15. Mankin, A. S., Zyrianova, I. M., Kagramanova, V. K. \& Garrett, R. A. Introducing mutations into the single-copy chromosomal $23 \mathrm{~S}$ rRNA gene of the archaeon Halobacterium halobium by using an rRNA operon-based transformation system. Proc Natl Acad Sci U S A 89, 6535-9 (1992).

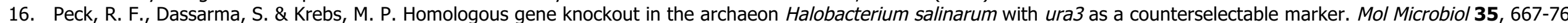
(2000).

17. Wang, G., Kennedy, S. P., Fasiludeen, S., Rensing, C. \& DasSarma, S. Arsenic resistance in Halobacterium sp. strain NRC-1 examined by using an improved gene knockout system. J Bacteriol 186, 3187-94 (2004).

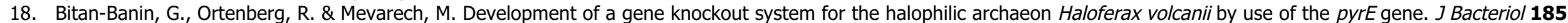
$772-8$ (2003).

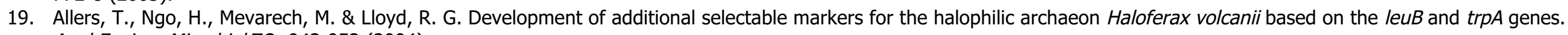
Appl Environ Microbiol 70, 943-953 (2004).

20. Gernhardt, P., Possot, O., Foglino, M., Sibold, L. \& Klein, A. Construction of an integration vector for use in the archaebacterium Methanococcus voltae and expression of a eubacterial resistance gene. Mol Gen Genet 221, 273-9 (1990).

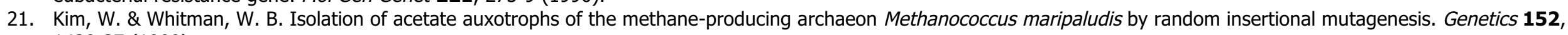
1429-37 (1999).

22. Sandbeck, K. A. \& Leigh, J. A. Recovery of an integration shuttle vector from tandem repeats in Methanococcus maripaludis. Appl Environ Microbio/ 57, 2762-3 (1991).

23. de Macario, E. C., Guerrini, M., Dugan, C. B. \& Macario, A. J. Integration of foreign DNA in an intergenic region of the archaeon Methanosarcina mazei without effect on transcription of adjacent genes. J Mol Biol 262, 12-20 (1996).

24. Berghöfer, Y. \& Klein, A. Insertional mutations in the hydrogenase vhc and frc operons encoding selenium-free hydrogenases in Methanococcus voltae. Appl Environ Microbiol 61, 1770-1775 (1995).

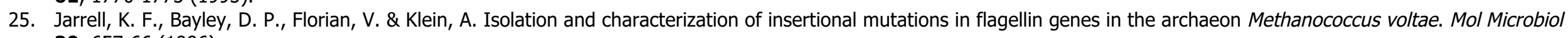
20, 657-66 (1996).

26. Metcalf, W. W. in Genetic Methods for Diverse Prokaryotes (eds. Smith, M. C. M. \& Sockett, R. E.) $277-326$ (Academic Press, London, 1999).

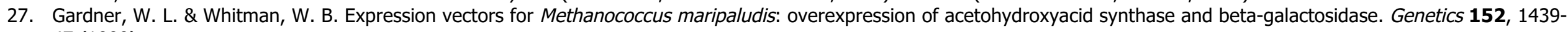
47 (1999).

28. Metcalf, W. W., Zhang, J. K., Apolinario, E., Sowers, K. R. \& Wolfe, R. S. A genetic system for Archaea of the genus Methanosarcina: liposome-mediated transformation and construction of shuttle vectors. Proc Natl Acad Sci U S A 94, 2626-31 (1997).

29. Zhang, J. K., White, A. K., Kuettner, H. C., Boccazzi, P. \& Metcalf, W. W. Directed mutagenesis and plasmid-based complementation in the methanogenic archaeon Methanosarcina acetivorans C2A demonstrated by genetic analysis of proline biosynthesis. $J$ Bacteriol 184, 1449-54 (2002).

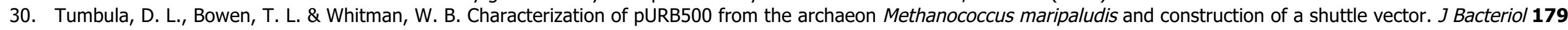
2976-86 (1997).

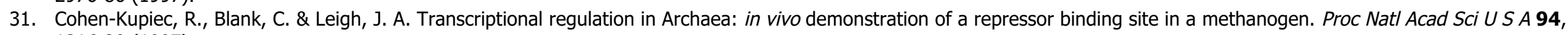
1316-20 (1997).

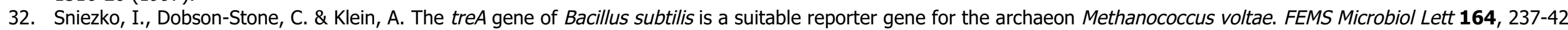
(1998). 


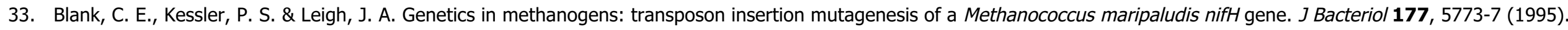

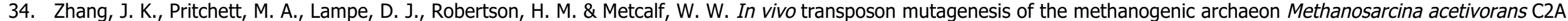
using a modified version of the insect mariner-family transposable element Himar1. Proc Natl Acad Sci U S A 97, 9665-70 (2000).

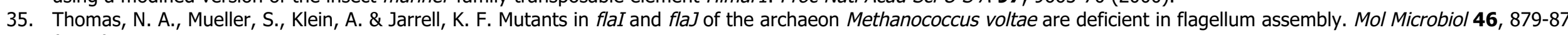
(2002).

36. Pritchett, M. A., Zhang, J. K. \& Metcalf, W. W. Development of a markerless genetic exchange method for Methanosarcina acetivorans C2A and its use in construction of new genetic tools for methanogenic archaea. Appl Environ Microbiol 70, 1425-33 (2004).

37. Moore, B. C. \& Leigh, J. A. Markerless mutagenesis in Methanococcus maripaludis demonstrates roles for alanine dehydrogenase, alanine racemase, and alanine permease. J Bacteriol (In press)

38. Argyle, J. L., Tumbula, D. L. \& Leigh, J. A. Neomycin resistance as a selectable marker in Methanococcus maripaludis. Appl Environ Microbiol 62, 4233-7 (1996).

39. Pfeiffer, M., Bestgen, H., Burger, A. \& Klein, A. The vhuU gene encoding a small subunit of a selenium-containing [NiFe]-hydrogenase in Methanococcus voltae appears to be essential for the cell. Arch Microbiol 170, 418-26 (1998).

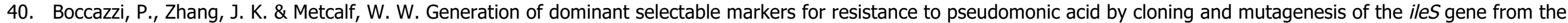
archaeon Methanosarcina barkeri fusaro. J Bacteriol 182, 2611-8 (2000).

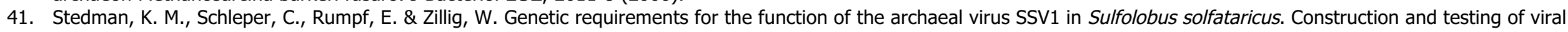
shuttle vectors. Genetics 152, 1397-405 (1999).

42. Cannio, R., Contursi, P., Rossi, M. \& Bartolucci, S. An autonomously replicating transforming vector for Sulfolobus solfataricus. J Bacteriol 180, $3237-40$ (1998).

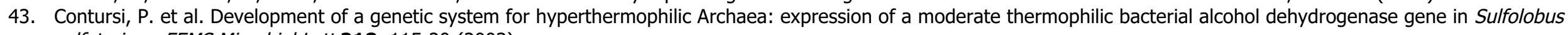
solfataricus. FEMS Microbiol Lett 218, 115-20 (2003).

44. Bartolucci, S., Rossi, M. \& Cannio, R. Characterization and functional complementation of a nonlethal deletion in the chromosome of a beta-glycosidase mutant of Sulfolobus solfataricus. J Bacteriol 185, 3948-57 (2003)

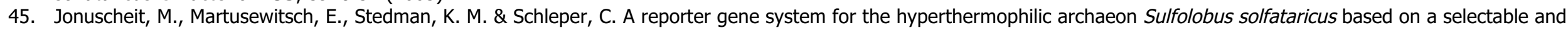
integrative shuttle vector. Mol Microbiol 48, 1241-52 (2003).

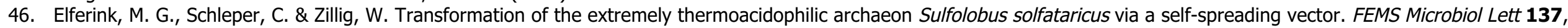
31-5 (1996).

47. Zillig, W. et al. Screening for Sulfolobales, their plasmids and their viruses in Icelandic solfataras. Syst Appl Microbio/ 16, 609-628 (1994).

48. Zillig, W. et al. Viruses, plasmids and other genetic elements of thermophilic and hyperthermophilic Archaea. FEMS Microbiol Rev 18, 225-36 (1996).

49. Aagaard, C. et al. General vectors for archaeal hyperthermophiles: strategies based on a mobile intron and a plasmid. FEMS Microbiol Rev 18, 93-104 (1996).

50. Aravalli, R. N. \& Garrett, R. A. Shuttle vectors for hyperthermophilic archaea. Extremophiles 1, 183-91 (1997)

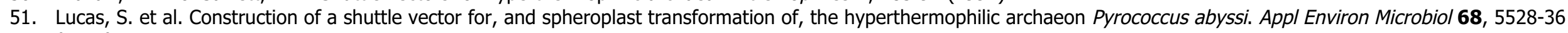
(2002).

52. Sato, T., Fukui, T., Atomi, H. \& Imanaka, T. Targeted gene disruption by homologous recombination in the hyperthermophilic archaeon Thermococcus kodakaraensis KOD1. J Bacteriol 185, 210-20 (2003). 